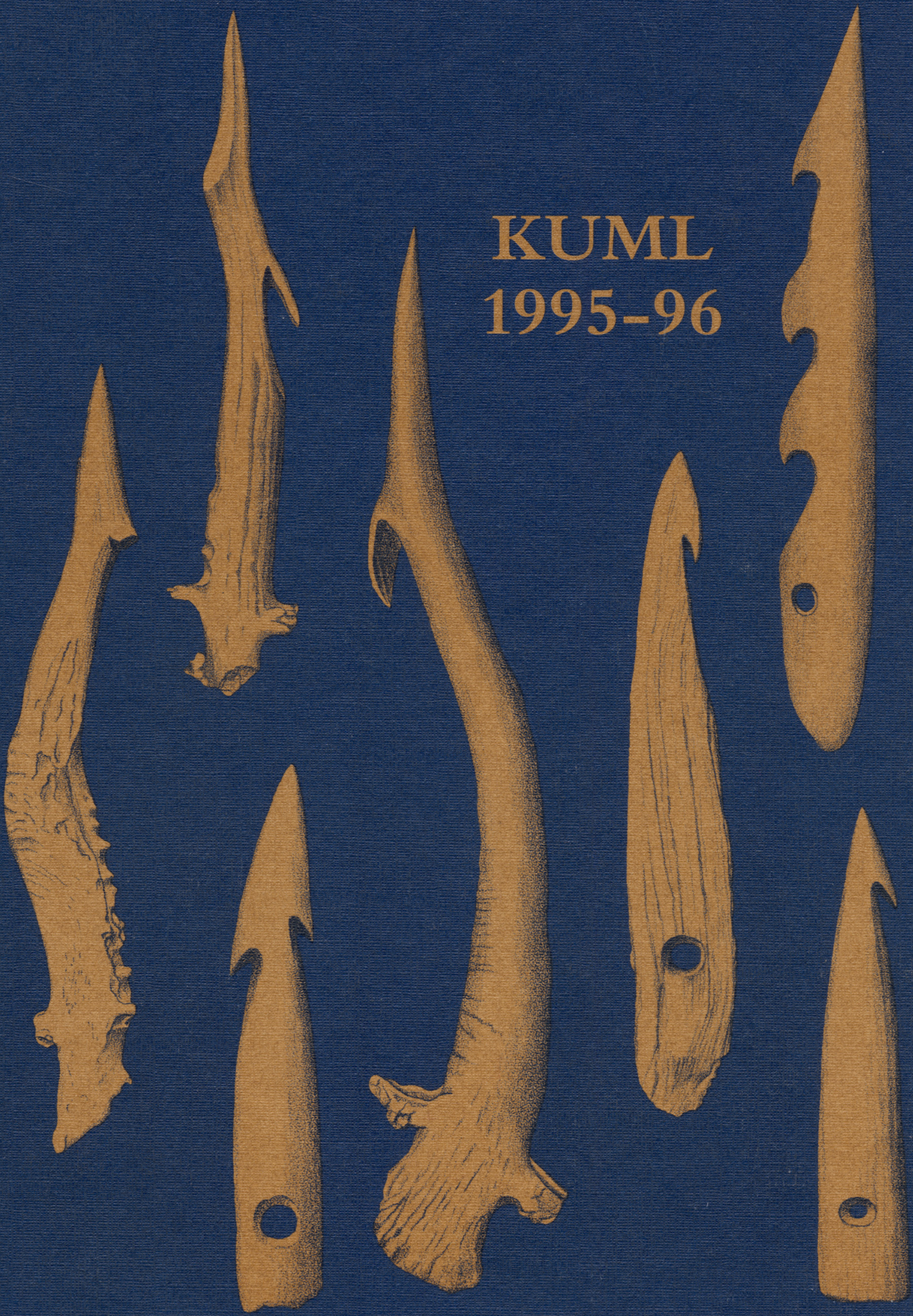


KUML 1995-96 


\section{KUML 1995-96 \\ Årbog for Jysk Arkæologisk Selskab}

With summaries in English

I kommission hos Aarhus Universitetsforlag, Århus 
Redaktion: Hans Jørgen Madsen og Jesper Laursen

Omslag: Jorgen Mührmann-Lund

Grafisk tilretteloggelse: Elsebet Morville

Tryk: Narayana Press

Skrift: Bembo 12/13

Papir: $115 \mathrm{~g}$ Arctic Silk

Copyright (C) 1997 by Jysk Arkcoologisk Selskab

ISBN 87-7288-592-0

ISSN 0454-6245 


\section{Indhold/Contents}

Palle Friis: Poul Kjærum. Worsaae-medaillen 16. maj 1996 ............................. 7

Poul Kjærum. Worsaae medal ........................................................ 10

Ole Høiris: Kampen om stenalderen. Antropologiske bud på vor oprindelse

i fortid og nutid ..................................................................................... 13

Fight over the Stone Age ................................................................. 44

Søren H. Andersen: Ertebølleharpuner og spækhuggertænder. Aspekter af marin fangst i Ertebølletid ............................................................. 45

Ertebølle harpoons and killer whale teeth. Aspects of marine hunting

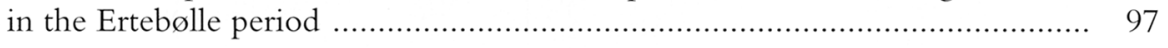

Klaus Ebbesen: Terningspil i yngre stenalder …........................................ 101

Dice and Dicing in the Stone Age ............................................... 111

Carsten Korthauer: En ældre romertidsgrav med guldmønt fra Jylland - samt nogle iagttagelser om møntomløb og -funktion i jernalderens Danmark ......... 113

An Early Roman Iron Age Grave containing a Roman Gold Coin ............. 133

Poul Mikkelsen og Lis Helles Olesen: Vendeldiget ........................................... 135

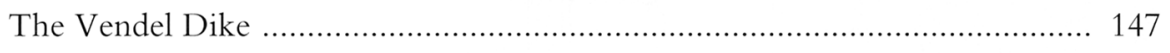

Jens Jeppesen og H.J. Madsen: Trækirke og stormandshal i Lisbjerg ...................... 149

A Wooden church and Big Man's Hall at Lisbjerg ..................................... 169

Mogens Rud: En skjult sandhed i Bayeux-tapetet? Hvad skulle Harald

Godwinson i Normandiet? ....................................................... 173

A hidden Revelation in the Bayeux tapestry? What was Harald

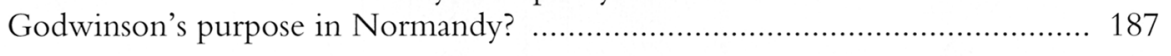

Hans Skov: Udgravningerne ved Aarhus Katedralskole i 1994-95 ....................... 189

Excavations at Aarhus Cathedral School in 1994-95 .................................. 206

Jette Linaa Larsen: Skår i tusindtal - keramik fra Torvet i Horsens

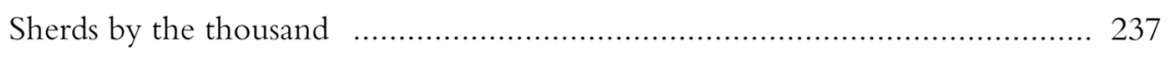

Jens Andersen: Jydepotter fra Brønderslev ................................................. 239

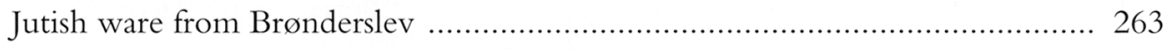

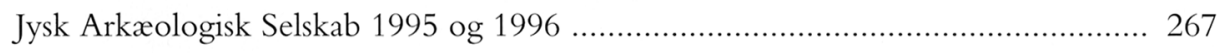




\title{
Jydepotter fra Brønderslev
}

\author{
Af Jens Andersen
}

Endnu i begyndelsen af 1900-årene fremstillede man enkelte steder i Jylland den karakteristiske keramiktype, som kaldes jydepotte. Frem til midten af det foregående århundrede var der imidlertid hele jyske egne, hvor en sådan produktion fandt sted. De vigtigste produktionsområder var Varde-egnen, Fjends herred mellem Viborg og Skive samt Vorup ved Randers, men der fandtes også en del mindre centre - således Vester Brønderslev i Vendsyssel, som vil blive behandlet i den følgende artikel (1).

Produktionen af jydepotter foregik overvejende som en bibeskæftigelse ved siden af landbrugsdrift - i nogle distrikter havde den dog nærmest karakter af industri. På Varde-egnen var der således i 1800-årenes første halvdel tale om en egentlig professionalisering, idet tjenestepigerne om sommeren ofte udtrykkeligt blev ansat på gårdene til at lave potter. En enkelt pottepige kunne i løbet af en sommer fremstille ca. 3000 potter. Omkring 1840, hvor produktionen havde sit højdepunkt, antages det, at der i hele landet produceredes ca. 1,8-1,9 millioner potter om året (2).

Jydepotten adskilte sig tydeligt fra den professionelt fremstillede keramik på farven og godset. Jydepotterne blev gennemgående banket ud af leret i modsætning til det professionelt fremstillede lertøj, som var drejet op på drejeskive. Desuden havde jydepotterne en farve, som varierede mellem grå og sort, fordi de var brændt ved forholdsvis lave temperaturer i et iltfattigt miljø. Jydepotterne blev derfor også i de egne, hvor de blev produceret, blot kaldt "sorte potter". Karrenes overflader kunne desuden være efterbehandlet ved gniden med en sten, "glitning", så de blev skinnende blanke.

De ældste fund af keramik med jydepotte-lignende karakter er gjort i Østjylland og stammer fra 1400-årene (3). Den enkle fremstillingsteknik og jydepotternes lighed med jernalderkeramik har dog tidligere fået en del forskere til at mene, at der var en direkte forbindelse mellem jydepotterne og jernalder-keramikken (4).

Jydepotten er altså en keramikform, som har været i brug i mindst 500 år. Alligevel er det vanskeligt at datere den, bl.a. fordi jydepotterne har fået meget lidt opmærksomhed i den arkæologiske litteratur. Årsagen hertil er dels, at man har anset keramiktypen for at tilhøre "nyere tid", d.v.s. perioden efter 1536, og derfor ment, at den var mindre interessant, 
og dels at den middelalderarkæologiske forskning overvejende har koncentreret sig om den tidlige del af middelalderen. Endnu en medvirkende årsag til manglen på interesse har formodentlig været, at keramiktypen antages ikke at have været så modtagelig for nye strømninger og ændringer som det professionelt fremstillede lertøj. Endelig er jydepotternes former i meget høj grad egnsbestemte. En datering opnået på materiale fra en bestemt del af landet er således ikke nødvendigvis gyldig for resten af landet, som det ellers antages for det professionelt fremstillede lertøj.

Erkendelsen af, at jydepotterne dukker op før middelalderens slutning, og en stigende interesse for perioden efter 1536, gør det imidlertid $ø n s k e l i g t$ at kende jydepotternes udvikling nøjere. Det er nemlig forudsætningen for at kunne fastslå skårenes alder og oprindelse, når de findes $\mathrm{i}$ forbindelse med udgravninger. Det er målet med denne artikel at forsøge at skabe en øget viden om jydepotternes former i Vendsyssel.

Fra skriftlige kilder ved vi, at der endnu i 1800-årene var en vis produktion af jydepotter i Vendsyssel, koncentreret i landsbyen Vester Brønderslev. Af og til dukker der også fysiske spor frem af denne produktion i form af gruber med fejlbrændte potter. Sidste gang man stødte på en sådan grube var ved Paukærgård i 1978. Vendsyssel historiske Museum erhvervede sig ved denne lejlighed en større samling jydepotteskår - i alt $305 \mathrm{~kg}$, svarende til 30 frugtkasser.

Dette fund vil i det følgende blive beskrevet nærmere. Skårsamlingen udgør nemlig på grund af sin størrelse en god mulighed for at fă et indblik i hvilke kartyper, der blev produceret på et givet tidspunkt. Endelig lader fundet sig nogenlunde præcist datere, da der i forbindelse med gruben er fundet professionelt fremstillet keramik, som kan dateres med noget større sikkerhed. Det er desuden af særlig interesse at fă beskrevet materiale fra Vester Brønderslev, da karformerne fra Vendsyssel er nærmest ukendte (5).

\section{Fundet og udgravningen}

18. april 1978 fik Vendsyssel historiske Museum melding om, at man i forbindelse med kloakeringsarbejde ved Brønderslev Kommunes nye materielgård var stødt på potteskår (6).

Museets arkæolog, Per Lysdahl, besigtigede stedet, og det viste sig, at der var tale om en grube med jydepotteskår. Gruben havde under gravearbejdet făet fjernet den vestlige del, så dens profil stod synlig i den nord-sydgående jordvæg (fig. 1 og 2). Gruben var dækket af et tykt muldlag, som nord for gruben var 1,2 $\mathrm{m}$ og syd for $0,9 \mathrm{~m}$ tykt. Muldlaget gik lidt ned i gruben. Det var ikke muligt at udskille nogen nedgravningsgrænse i mulden. Gruben målte ca. 5,5 m i tværsnit foroven og dens bund lå ca. $2 \mathrm{~m}$ under den nuværende jordoverflade. 
Fig. 1. Skitse af skårgrubens østprofil, 1:100. Lagbeskrivelse: 1. Muldjord. 2. Skårlag, 3. Nedflydt sand. 4. Gult undergrundssand. Opmåling: Per Lysdahl.

Sketch of the section through the pit, 1:100. Description of layers: 1 . Top soil. 2. Sherd layer. 3. Downwashed sand. 4. Yellowish sand - subsoil. Measures: Per Lysdahl.

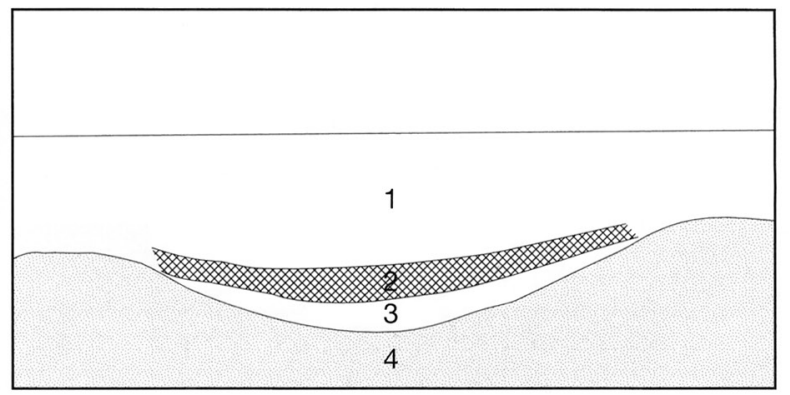

Nederst $\mathrm{i}$ gruben lå et ca. $30 \mathrm{~cm}$ tykt lag af nedflydt sand. Herover lå et ca. $30 \mathrm{~cm}$ tykt, kompakt lag af lerkarskår med enkelte lerklumper. Mellem skårene var der sort jord.

Den stående profilvæg blev afrenset, fotograferet og skitsemæssigt opmålt. Den resterende del af gruben blev derefter udgravet. Dette skete med rendegraver, idet det øverste muldlag blev fjernet. Derefter blev rendegraverens grab ført under skårlaget, som blev taget op i flere klumper. De opgravede skårklumper samt den opgravede jord fra selve grøftegravningen blev gennemgået på stedet og skårene sorteret fra og bragt til museet.

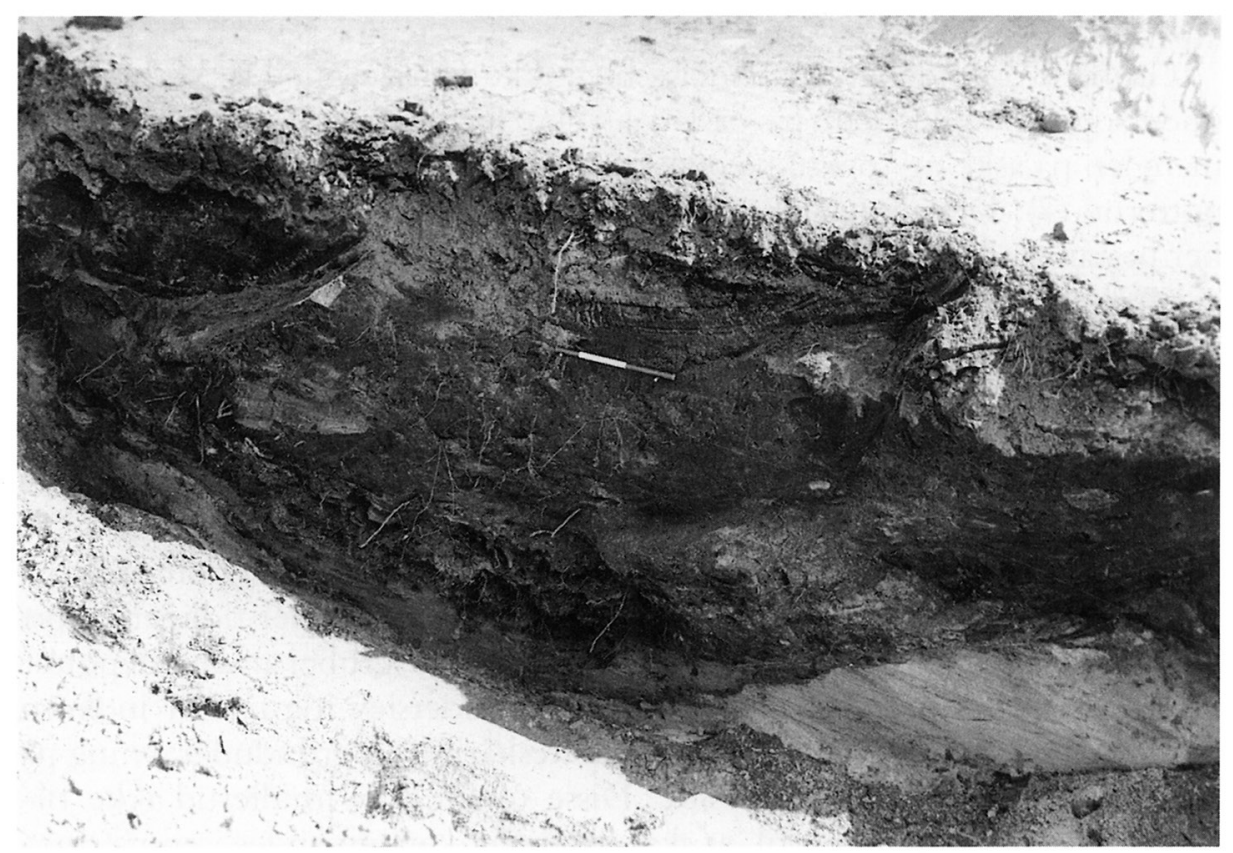

Fig. 2. Foto af den gennemskårne skårgrube, set mod nord. Foto: Per Lysdahl.

Photo of the cut pit, from the south. Photo: Per Lysdahl. 


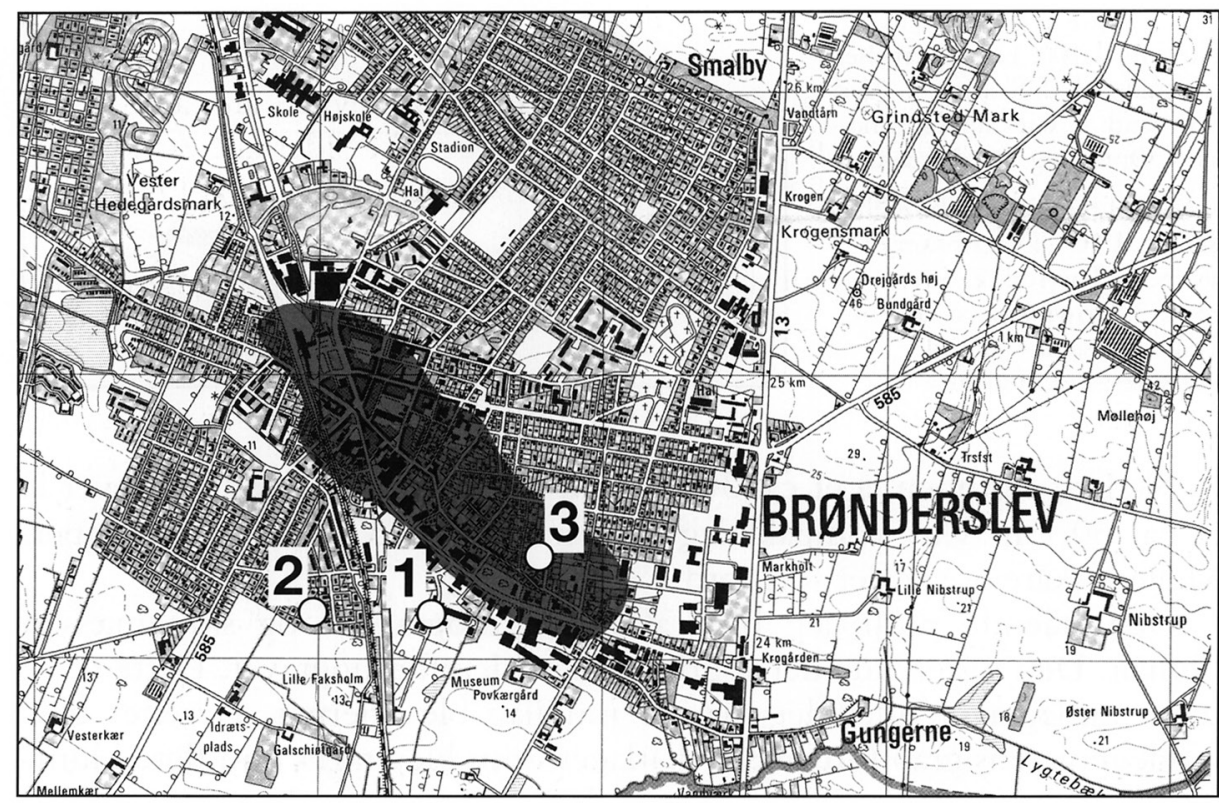

Fig. 3. Det nuværende Brønderslev med bebyggelsens udstrækning 1804 angivet med skravering. Fundsteder af jydepotter: 1. Paukærgård, 2. Kongstedet, 3. Bundgårdsvej.

The present town of Brønderslev with the extent of the village in 1804 marked with hatching. Find sites with large amonunts of jutish ware: 1: Paukærgård, 2: Kongstedet, 3. Bundgårdsvej.

Grubens oprindelige anvendelse blev ikke fastslået med sikkerhed ved undersøgelsen. Der kan på grund af den forholdsvis store dybde samt manglen på aske og trækul næppe være tale om en ildgrav til brænding af potterne (7). Det drejer sig snarere om en sandgrav, idet undergrunden her består af sand.

Gruben blev sekundært anvendt som affaldskule for jydepotteskår, som efter alt at dømme er rester fra en stedlig produktion. Gruben indeholdt desuden nogle få skår af glaseret lertøj, hvis tilstedeværelse ikke uden videre kan forklares, da den ellers ikke synes at have indeholdt fund, som kunne tyde på en anvendelse som almindelig affaldsgrube, såsom tegl, glas, pibestilke eller knogler.

Paukærgård-potterne er ikke den eneste samling jydepotteskår på Vendsyssel historiske Museum, for ved Brønderselv er der tidligere gjort lignende fund (fig. 3). Der blev 1959 fundet flere gruber med jydepotter ved Kongstedet umiddelbart sydvest for Brønderslev, og i 1971 indkom der til museet en større mængde jydepotteskår fra en grundudgravning på Bundgårdsvej i selve Brønderslev. Disse to fund er imidlertid ikke tilstrækkeligt dokumenteret til, at skårmaterialet kan anvendes i en nærmere analyse. 


\section{Skårmaterialet}

Jydepottematerialet fra Paukærgård omfatter som nævnt i alt ca. $305 \mathrm{~kg}$. Da en stor del af materialet består af ukarakteristiske sideskår, er der kun gjort forsøg på at kvantificere materialet nøjere for nogle enkelte, meget karakteristiske kartyper.

På grund af skårmaterialets meget ensartede karakter og fragmenterede tilstand har det kun $\mathrm{i}$ begrænset omfang været muligt at samle skårene til hele kar. Det har således været vanskeligt at rekonstruere karformerne, idet det kun sjældent er muligt at skabe forbindelse mellem bund og rand. Dette forhold gør sig især gældende for de større kartypers vedkommende; hvorimod det ved de mindre kartyper i højere grad har været muligt.

Trods disse problemer vil jeg i det følgende præsentere de kartyper, som findes i Paukærgård-materialet.

\section{Generel beskrivelse af materialet}

Skårene har en stort set ensartet tykkelse på omkring $0,5 \mathrm{~cm}$. Skærven er lysegrå, mens den ind- og udvendige overflade gennemgående er sort. Der findes dog også en del skår med sandfarvede overflader, hvilket dog antageligt skyldes fejl i brændingen. Godset er fint magret med små sandskorn.

Karrene synes alle fremstillet $i$ hånden ved udbankning. Der ses ingen spor efter brug af drejeskive. Derimod er der spor af skarving, d.v.s. skrælning af de læderhårde kar til den rette tykkelse med kniv, samt af glitning, d.v.s. gniden på karrenes sider med en sten for at skabe en glinsende overflade.

Den meget store mængde ensartet lertøj i Paukærgård-fundet tyder umiddelbart på, at der er tale om affald fra potteproduktion. Der er imidlertid ikke konstateret ret mange sikre fejlbrændinger. En vigtig årsag hertil er antagelig materialets fragmenterede tilstand, som gør det vanskeligt at påvise sprængninger, revner og deformering opstået under brændingen. Jydepotternes lave brændingstemperatur $i$ ildgraven betyder, at de stærkt forvredne former, som ses på fejlbrændinger fra pottemagerovne, ikke forekommer.

Alligevel er det lykkedes at påvise en række forskellige skader, som må være opstået $\mathrm{i}$ forbindelse med brændingen. Tydeligst ses det på en lysestage/lampe, som synes at være flækket under brændingen, idet brudfladerne er helt mørke som efter reduceret brænding. Noget lignende ses på randen af et af de kraftige kar. På andre kar ses det, at ydersiden er skallet af i op til 0,15 cm tykke flager. Det drejer sig om kar med sandfarvet gods. Disse skader skyldes antageligt en for hurtig afkøling i fri luft. På atter andre kar ses det, at overfladerne er krakelerede; disse skader ses på helt mørke kar. 
Der fandtes ingen spor af brug på potterne i form af udvendig sodning eller fastbrændte madrester på indersiden, og der var ligeledes ingen tegn på slid af tæer eller bunde. Alt dette tyder på, at der er tale om affald fra produktion og ikke om kasserede, brugte kar.

Som det vil fremgå af den nedenstående gennemgang står vi overfor en varieret produktion, som dog alligevel har et meget ensartet præg.

\section{Kartyper}

Nedenfor er de påviste kartyper opdelt i fire hovedgrupper efter formodet anvendelse: I. Kogekar, II. Bordkar, III. Opbevaringskar og IV. Lys og varme.

\section{Kogekar}

\section{Stjertpotter}

Stjertpotterne udgør et mindre indslag i materialet fra Paukærgård. Der er optalt 33 stjerte, som sandsynlighed stammer fra stjertpotter; i de tilfælde, hvor kun selve stjerten er til stede, er det dog ikke muligt med fuldstændig sikkerhed at fastslå, om stjerten stammer fra en potte eller pande.

Stjertpotterne har en randdiameter på 20-22 cm. Et enkelt eksemplar har dog en randdiameter på kun ca. $16 \mathrm{~cm}$. Randen er almindeligvis udadbøjet med rundet randlæbe (fig. 4a-b). Eksemplaret med den lille randdiameter har dog indadbøjet rand (fig. 4c).

Stjerten har karakter af en 5-8 cm lang, rullet pølse, som er fastgjort til karsiden 3-4 cm under randen (fig. 5 og 6). I enden af stjerterne ses en

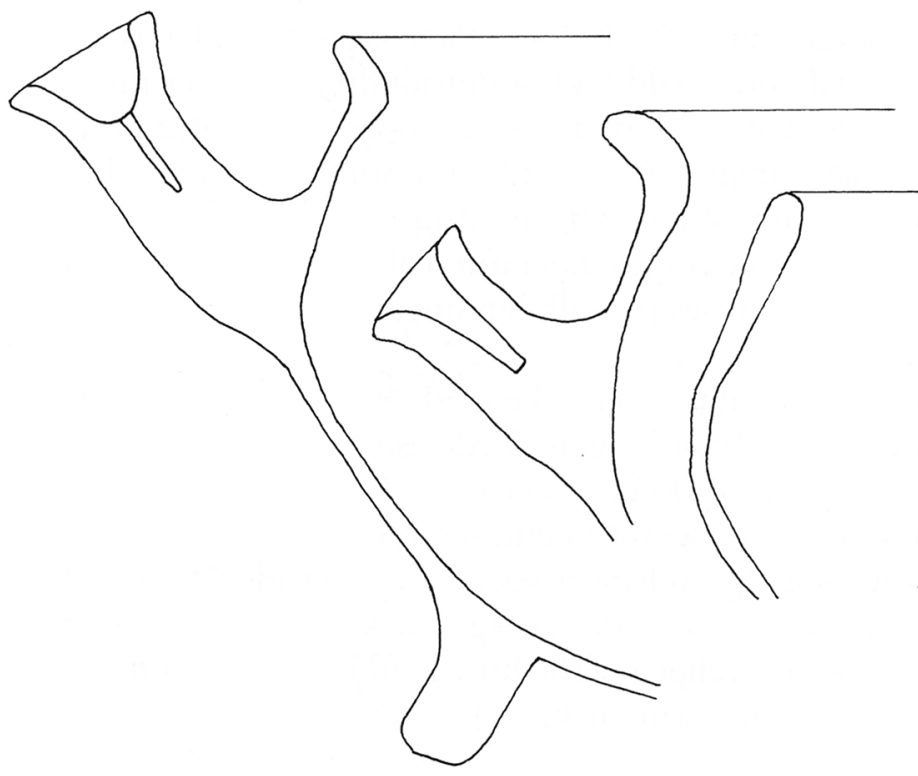

Fig. 4a-c. Stjertpotters randprofiler. Tegning: J.A. $1: 2$.

Rim shapes of longhandled pots. Drawing: J.A. 1:2. 

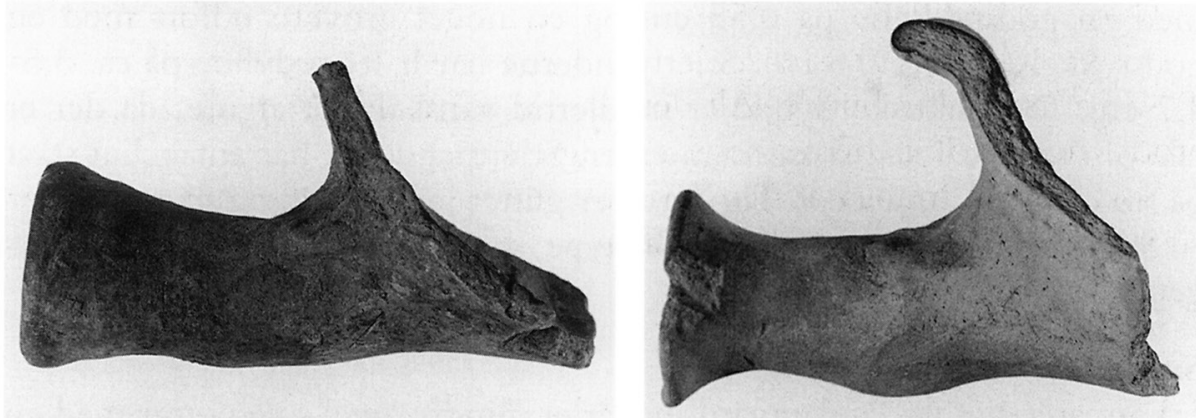

Fig. 5. Stjerters udformning. Foto: Ole Brønden. 1:2.

Fig. 5. Different versions of long handles. Photo: Ole Brønden. 1:2.

$1,5 \mathrm{~cm}$ dyb fordybning, som fliger skaftenden ud. I bunden af denne fordybning er boret et mindre, ca. $2 \mathrm{~cm}$ dybt hul.

Selve karret er ved stjertpotterne forholdsvist lavt og har rundet bund med tre tæer. Den ene af disse er altid anbragt direkte under stjerten. Tæerne er ca. $3 \mathrm{~cm}$ høje og afrundede med lidt facettering. Karrene var alle glittet på indersiden af randen og indvendigt på bunden. Indvendigt er karrene sorte eller mørkegrå, mens farven udvendigt varierer fra sandfarvet over grå til sort.

Stjertpotten var en alsidig kartype, som har kunnet anvendes til både stegning og kogning. Karrenes forholdsvis lille rumindhold har dog begrænset anvendelsesmulighederne en del, idet de var for små til brug som egentlige kogegryder.

\section{Stjertpander}

Stjertpander udgør et beskedent indslag af skårmaterialet. Der er med sikkerhed fundet dele af mindst fem stjertpander, men antallet kan dog være lidt større.

Panderne har haft en randdiameter på ca. 26-27 cm. Randen er ufortykket og rundet. Stjerten er fastgjort direkte på randen; det meste på undersiden, på oversiden ses den som en fortykkelse. Stjerten svarer i udformning egentlig til stjertpottens, men et par eksemplarer er særligt tynde og fint udført (fig. 6).

I det hele taget synes der at have været to udgaver af stjertpanden: en fint glittet

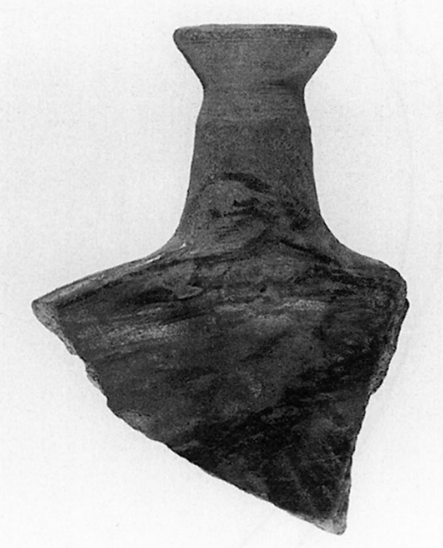

Fig. 6. Randparti af stjertpande med stjert. Foto: Ole Brønden. 1:2.

Rim fragment of long-handled pan. Photo: Ole Brønden. 1:2. 
med en godstykkelse på $0,55 \mathrm{~cm}$ og en noget grovere udført med en godstykkelse på ca. $0,8 \mathrm{~cm}$. Stjertpanderne har haft en dybde på ca. 3,5$4,7 \mathrm{~cm}$. Den faktiske dybde er imidlertid vanskelig at afgøre, da der er tale om temmeligt små karfragmenter. Stjertpanderne har antageligt stået på tre ca. $3 \mathrm{~cm}$ høje tæer. Panderne er glittet indvendigt og på randen.

Stjertpanderne er en velkendt kartype, som har været anvendt som stegepande.

\section{Små potter}

I skårmaterialet fra Paukærgård indgår et mindre antal små potter med en dybde på ca. $11 \mathrm{~cm}$ (fig. 7).

De har gennemgående haft en randdiameter på ca. $11 \mathrm{~cm}$, og findes med to varianter af randudformningen, som dog er temmelig lig hinanden. Randen var let udadbøjet og halsen profileret med to vandrette riller.

Potterne har jævnt rundede sider. Vægtykkelsen er på ca. $0,5 \mathrm{~cm}$. De små potter findes med to forskellige bundudformninger: flad bund og rundet bund med tæer. Det har ikke været muligt at forbinde de runde bunde med randpartier, så det kan ikke afgøres, om der har været forskel på udformningen af randen ved de to forskellige bundformer.

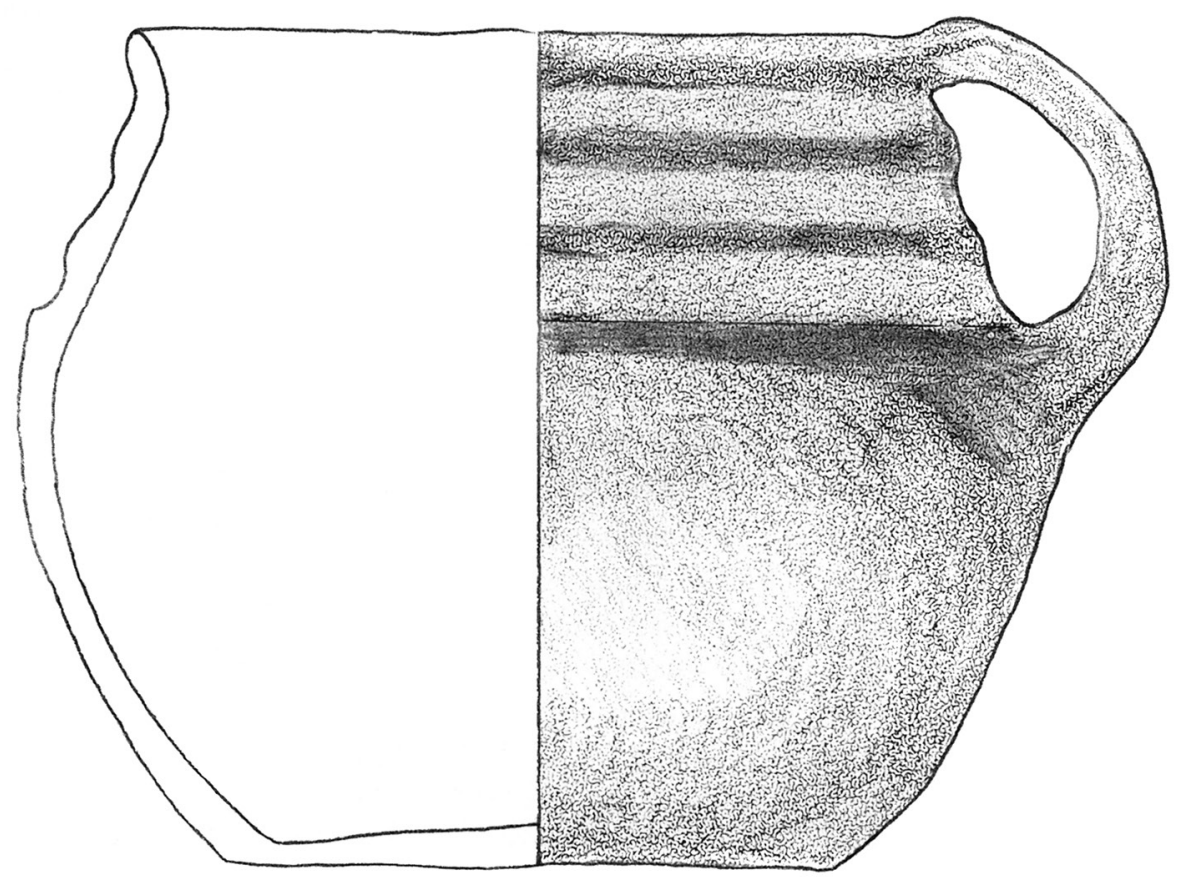

Fig. 7. Lille potte, fladbundet udgave. Tegning: J.A. 3:4. Little pot, flat based version. Drawing: J.A. 3:4. 
Potterne har lodrette, båndformede ører med bred rille, som er påsat randlæben. På et eksemplar, hvoraf 2/3 af randen er bevaret, kunne det konstateres, at den kun har haft et enkelt øre - om dette gælder for alle de små potter vides imidlertid ikke.

De små potter har åbenbart ikke været beregnet til almindelig madlavning, da deres rumindhold er meget ringe. Selve potternes form tyder imidlertid på, at det drejer sig om kogekar. De kan så muligvis have været brugt til opvarmning af en enkelt portion eller til særlige dele af maden (8).

Nære paralleller til disse potter er fundet i Oslo i lag, som dateres til slutningen af 1600-årene (9).

\section{Lave potter}

I materialet indgår nogle fă lave potter med en dybde på $8-9 \mathrm{~cm}$. De har ensartet randparti, men meget forskelligartet udformning af bunden.

Der er tale om kar med en randdiameter på $20-22 \mathrm{~cm}$. Randen er udadbøjet med rundet randlæbe. På et eksemplar er der fastgjort et øre på randen; om de øvrige eksemplarer har haft ører, og i givet fald hvor mange, kan ikke afgøres. Det bevarede øre er lodret og båndformet med bred rille.

Karrenes sider hælder temmeligt kraftigt mod bunden. Bundudformningen varierer imidlertid meget kraftigt, idet et eksemplar har haft flad bund. Et andet kars bund hvælver op på midten, så det hviler på en standrand.

De ovennævnte kar skal antageligt identificeres med den type, som af A.G. Jensen betegnes "flakninger" eller "boldkar" (10). Der var her først og fremmest tale om stegegryder.

Store kar

Denne gruppe er den hyppigst forekommende kartype i fundet, og den udgør antagelig mere end halvdelen af materialet.

Karrenes randdiameter varierer mellem 18 og $32 \mathrm{~cm}$. Hovedvægten ligger dog på en randdiameter på henholdsvis $18-20$ og $28-30 \mathrm{~cm}$. Randenes udformning varierer også temmeligt meget (fig. 8). Alle karrene har dog haft udadbøjet rand, og de fleste også rundet randlæbe. Den enkleste form, hvor randen nærmest kun er ombøjet, findes især hos de mindre kar, mens de større kar har en del variationer.

Alle karrene har antageligt haft ører. Ørerne er båndformede med bred rille og lodrette med den ene ende fastgjort på randen (fig. 9). Om karrene har haft et eller to ører kan ikke siges med sikkerhed, da der ikke er samlet nogen hele rande. Karrenes størrelse sandsynliggør dog, at de har haft to ører, da de ellers ville have været for uhåndterlige.

Trods den ganske store variation i randdiameteren, synes karrene at have været ganske ensartede i formen. Det var temmeligt dybe kar, men 


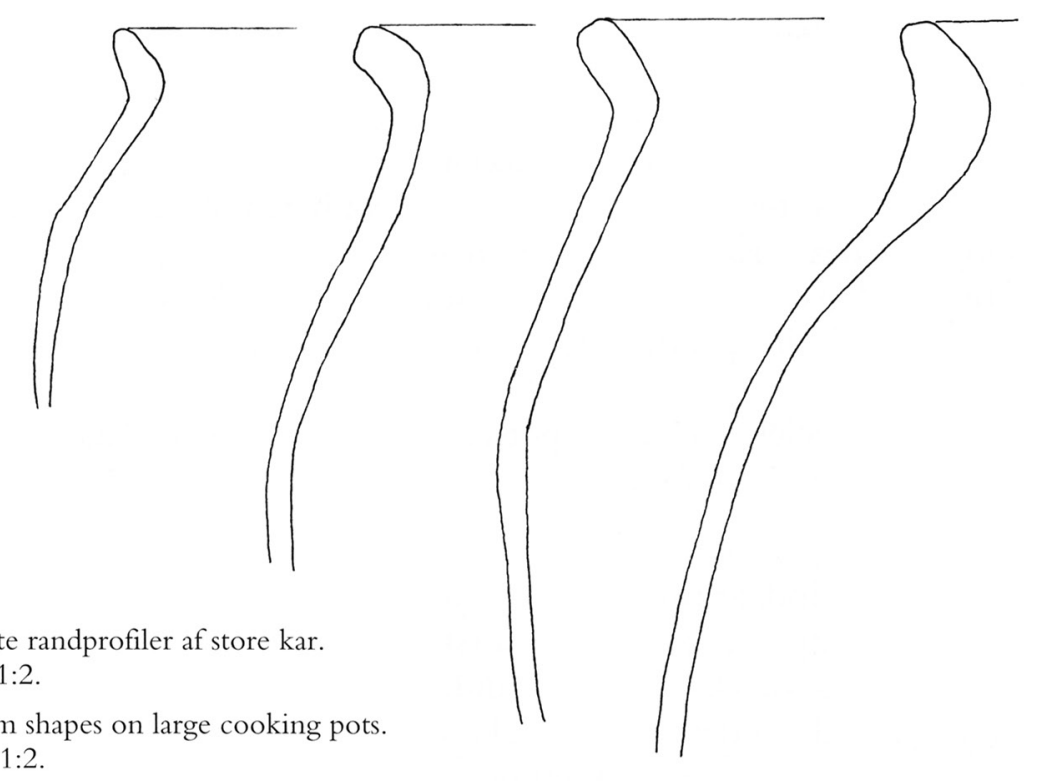

Fig. 8. Udvalgte randprofiler af store kar.

Tegning: J.A. 1:2

Selection of rim shapes on large cooking pots.

Drawing: J.A. 1:2.

her er der atter problemer med at bestemme de nøjagtige dimensioner på grund af materialets fragmentariske tilstand.

Det har ikke været muligt at forbinde rand- og bundpartier. Alligevel vil det på grund af det meget store antal rundede bunde med tæer, som findes i materialet, være rimeligt at antage, at alle karrene har haft en bund af denne type.
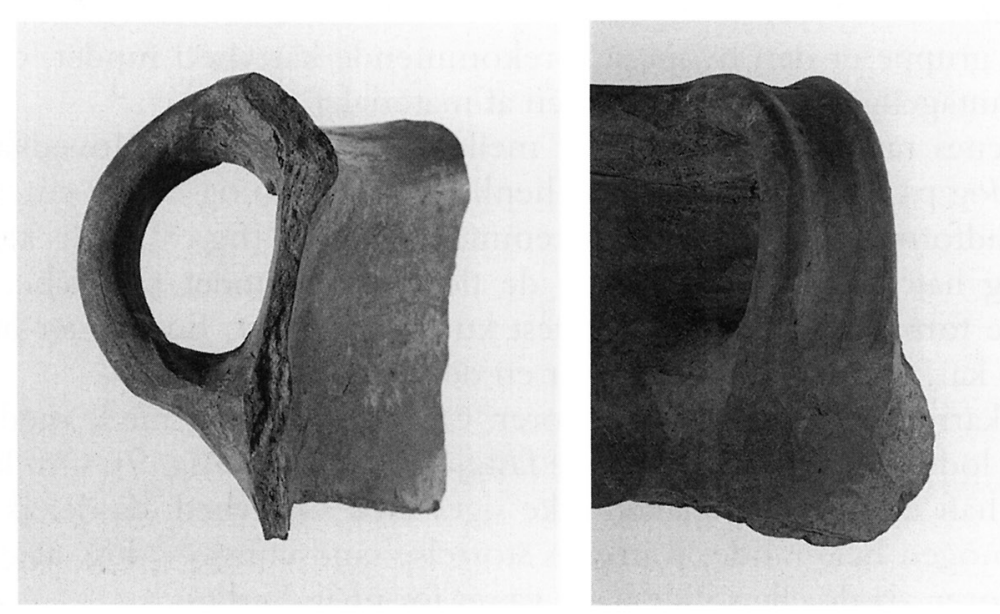

Fig. 9a-b. Ore på randparti af stort kar set fra forskellige vinkler. Foto: Ole Brønden. 1:2.

Ear on the rim of a large cooking pot, seen from different angles. Photo: Ole Brønden. 1:2. 
Karrenes godstykkelse varierer mellem 0,4 og 0,6 cm, men er dog jæun på de enkelte kar. Karrene har været glittede på den indre side af randen og indvendigt på bunden.

Den her omhandlede kartype var en egentlig kogegryde. Som jydepotte var typen i produktion lige frem til tiden, da det åbne ildsted blev afløst af jernkomfuret.

\section{Bordtoj}

Kander (fig. 10)

Kander udgør et temmeligt lille indslag i skårmaterialet.

Kanderne har en randdiameter på 8-10 cm. Randen er let udadbøjet og rundet, og halsen er facetteret med to-tre vandrette riller. Der er ingen hældeanordning $i$ form af tud eller lignende.

På randen er fastgjort en lang båndformet hank med bred rille. Den nedre ende af hanken var fastgjort på kandens bug. En fortykkelse indvendigt $i$ karrets skulder viser, at kanden er sat sammen af mindst to selvstændigt fremstillede dele: krop og hals. Kanderne har en temmeligt tykmavet krop, men det helt nøjagtige størrelsesforhold er usikkert, da ingen er samlet helt. Bundene er flade uden nogen former for standrand og har en diameter på ca. $9 \mathrm{~cm}$.

Kanderne har en temmelig omfattende glitning. I alle tilfælde er der glitning på halspartiet (fig. 10b). Der forekommer imidlertid også eksemplarer med omfattende mønsterglitning på bugen (fig. 10c). Glitningen må anses for overvejende dekorativ, idet indvendig glitning ville have været mere egnet til at gøre kanderne tætte; desuden indgår der jo i mønstrene uglittede partier.

Kanderne fra Paukærgård ligner i formen meget den kandetype, som begyndte at dukke op i 1200-årene. I sin glaserede udgave synes kandetypen at forsvinde op i 1400-årene. Den mindre fornemme, sortbrændte udgave af kanden fortsætter imidlertid med at være i brug til op i 1800årene.

Fragmenter af kander med et glittet mønster, der næsten er identiske med det, som findes på en del af Brønderslev-kanderne, er fundet i Oslo i lag fra ca. 1625-80 (11).

På grund af den omfattende dekoration i form af glitning må en anvendelse som bordkar komme på tale.

\section{Skåle}

Skålene udgør et mindre indslag i materialet.

Skålene har en randdiameter på 22-28 cm, og en dybde på ca. 8-10 $\mathrm{cm}$. At den beregnede diameter kan være noget misvisende, ses på fundets eneste hele skål (fig. 11): den direkte målte randdiameter varierede her mellem 22 og $23 \mathrm{~cm}$. Randene er normalt udadbøjede med rundet randlæbe. Der forekommer dog en del forskellige varianter. 


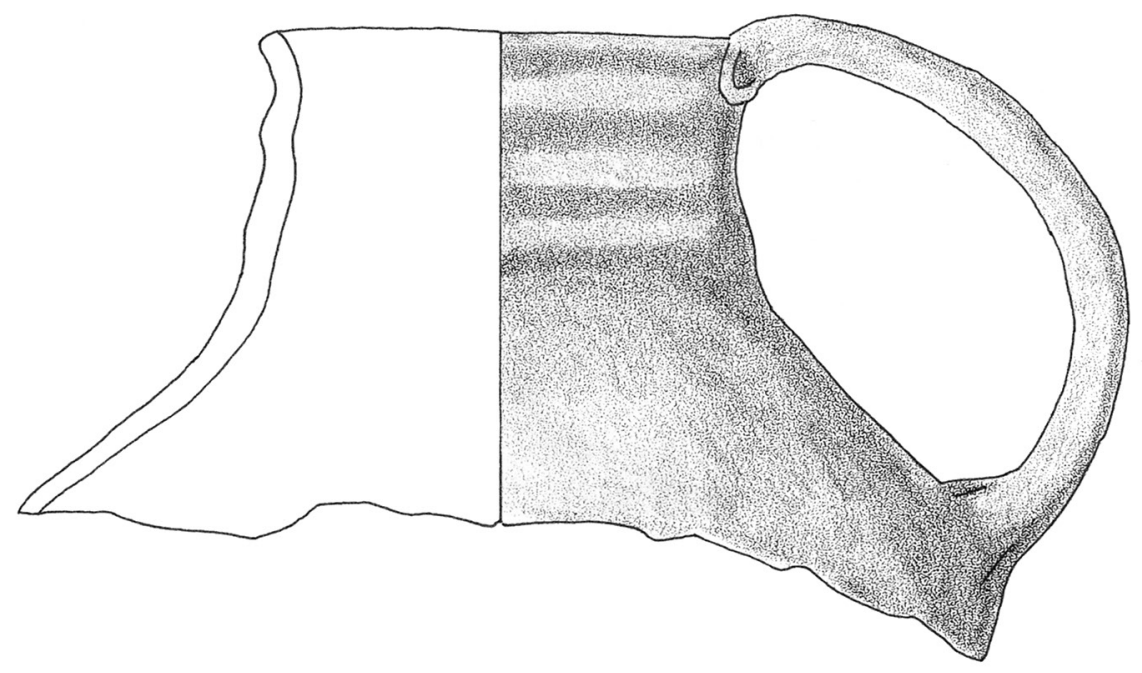

Fig. 10. Kande.

a. Halsparti.

b. Øvre del af korpus med glitning.

c. Nedre del af korpus med glittet dekoration.

Tegning: J.A. 1:2.

Jug. a. Neck fragment. b. Upper part of body with burnishing. c. Lower port of body with burnished decoration.

Drawing: J.A. 1:2.
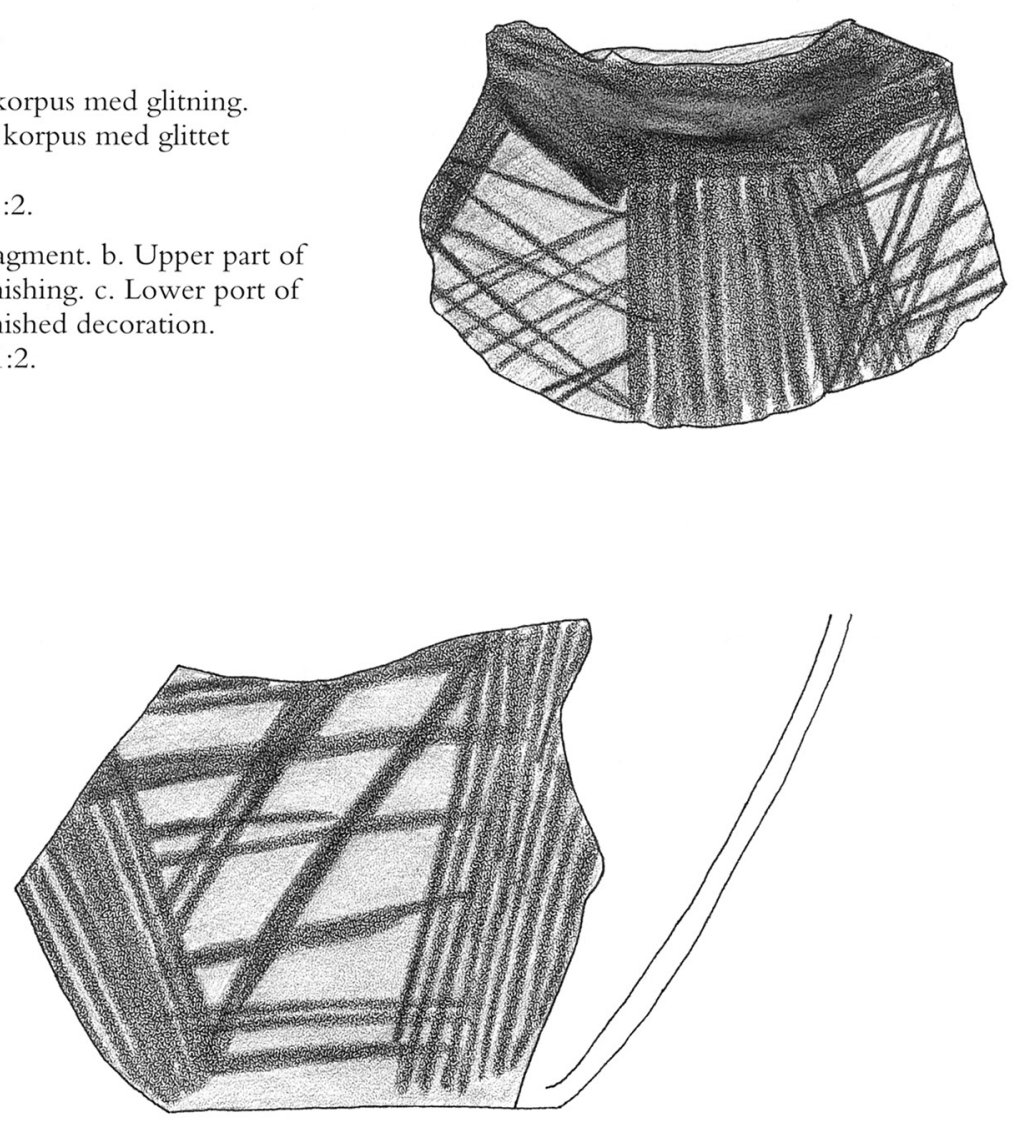


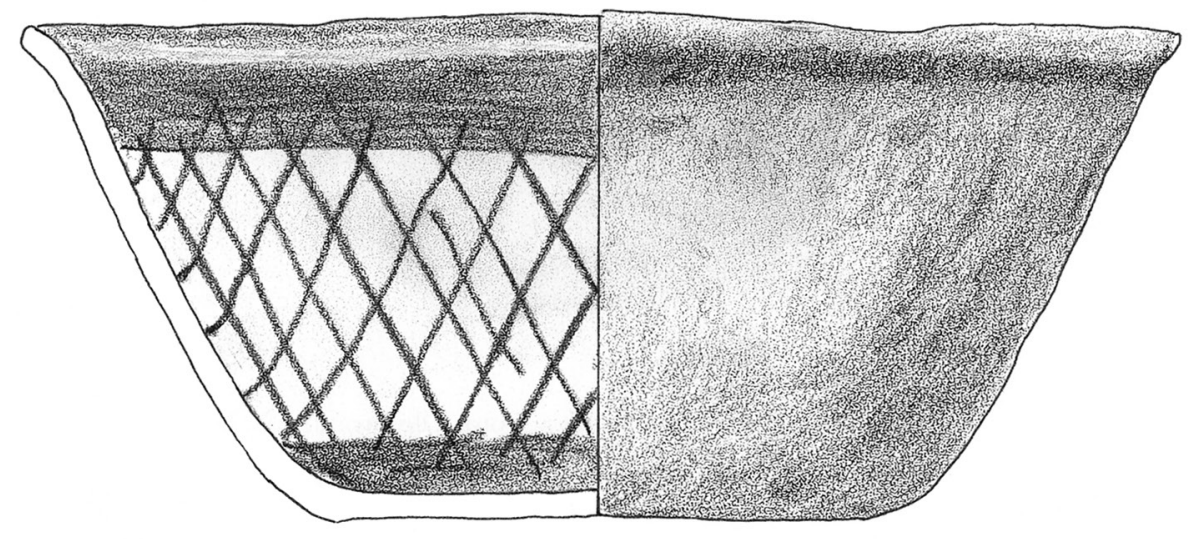

Fig. 11. Fuldstændigt bevaret skål med indvendig glitning. Tegning: J.A. 1:2.

Fully preserved bowl with internal burnishing. Drawing: J.A. 1:2.

Skålene har flad bund og jævnt udadhældende karvægge. Alle skålene er glittede, de fleste over hele den indre del. På nogle skåle var det imidlertid kun de øverste $3 \mathrm{~cm}$ af randen, som blev glittet heldækkende; derunder ses et rudermønster af skrå, glittede streger.

Der synes ikke at være nogen sammenhæng mellem variationerne i randform, randdiameter og udsmykningen; variationerne i randform og diameter må antageligt forklares med, at der netop var tale om håndlavede kar.

Hvad angår skålenes funktion er der to muligheder. De kan være brugt som søbefade, d.v.s. kar man spiste grød og lignende fra. Søbefadet var et fælles spisefad, som blev anbragt midt på bordet, og hver person spiste så deraf med sin egen ske. Den anden mulighed er en anvendelse som mælkefade for mælk, som skulle stå og trække til fløde (12). Det er ikke muligt med sikkerhed at afgøre, hvilken af funktionerne skålene har skullet opfylde - antageligt har de kunnet benyttes til begge formål, men deres glittede ornamentik tyder måske snarest på brugen som søbefade.

Små skåle

Der er i materialet fundet rester af en enkelt lille skål. Det drejer sig om ca. en halv skål, hvor bundpartiet dog mangler (fig. 12).

Skålen har en randdiameter på $14 \mathrm{~cm}$ og en bevaret dybde på ca. $4 \mathrm{~cm}$. Randen er fortykket og afrundet. Bundens udformning kan ikke afgøres. Godstykkelsen er $0,3 \mathrm{~cm}$ ved bunden og tiltog gradvist til $0,5 \mathrm{~cm}$ på randen. Skålen er glittet indvendigt i vandrette baner. Dens anvendelse er usikker. 


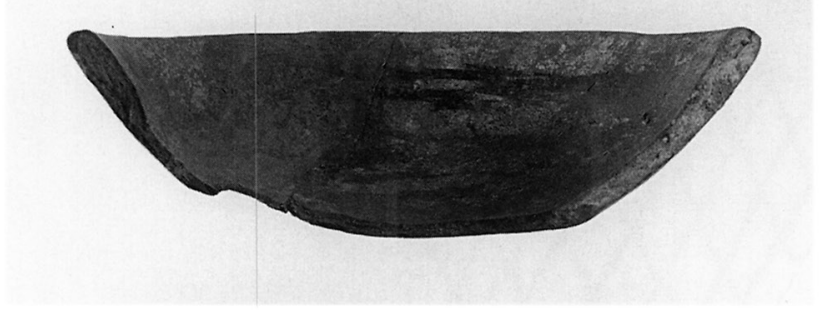

Fig. 12. Lille skål, set fra indersiden. Foto: Ole Brønden. 1:2. Little bowl, seen from the interior. Photo: Ole Brønden. 1:2.

Fade

Der findes nogle få fade i materialet fra Paukærgård.

Der er tale om kraftige og uregelmæssige kar med en godstykkelse, som varierer mellem 0,6 og 1,0 cm. Fadenes randdiameter er på ca. 27 $\mathrm{cm}$. Randen er let fortykket enten udvendigt eller indvendigt. På de tre større fragmenter, hvor dybden har kunnet måles, varierer denne fra 3,4 til $5,7 \mathrm{~cm}$. Bundenes underside er flad eller rundet.

Fadene giver ikke indtryk at være særlig omhyggeligt formede. Imidlertid lader det sig ikke med sikkerhed afgøre, om de har været glittede indvendigt, da alle fades overflader er krakelerede.

\section{Opbevaringskar}

\section{Kraftige kar}

Blandt materialet fra Paukærgård findes nogle få store kar med meget kraftige vægge. Skårene, som let lader sig udskille fra de øvrige, vejer i alt $12 \mathrm{~kg}$. Af randskårene fremgår, at det drejer sig om mindst seks kar.

Karrene har en randdiameter på ca. $32-40 \mathrm{~cm}$. Randformerne varierer så meget, at der faktisk findes en randtype for hvert kar (fig. 13). Randene er dog $i$ alle tilfælde indadhældende. Karvæggene er meget ujævne og synes ikke at have været udsat for nogen form for efterbearbejdning hverken skrabning eller glitning. Vægtykkelsen kan i samme højde på karret variere fra 0,45 til $0,9 \mathrm{~cm}$.

Karrene synes at have været fladbundede, idet der er fundet to fragmenter af denne godstype, som har tilhørt fladbundede kar. Det ene bundstykke er helt bevaret og har en diameter på ca. $16 \mathrm{~cm}, \mathrm{og}$ buler lidt op på midten.

Karrenes anvendelse er noget usikker. På grund af den meget varierende vægtykkelse og den store vægt kan de næppe have været anvendt som kogekar. Den flade bund, samt den omstændighed, at der ingen hanke findes, gør det sandsynligt, at det drejer sig om forrådskar. Der kan dog muligvis også være tale om lysestøbergryder, som også er karakteriserede ved at være tykvæggede. Lysestøbergryderne havde imidlertid som regel, 
Fig. 13. Kraftige kar et udvalg af randprofiler.

Tegning: J.A. 1:2

Coarse vessels - a selection of rim shapes. Drawing: J.A. 1:2.
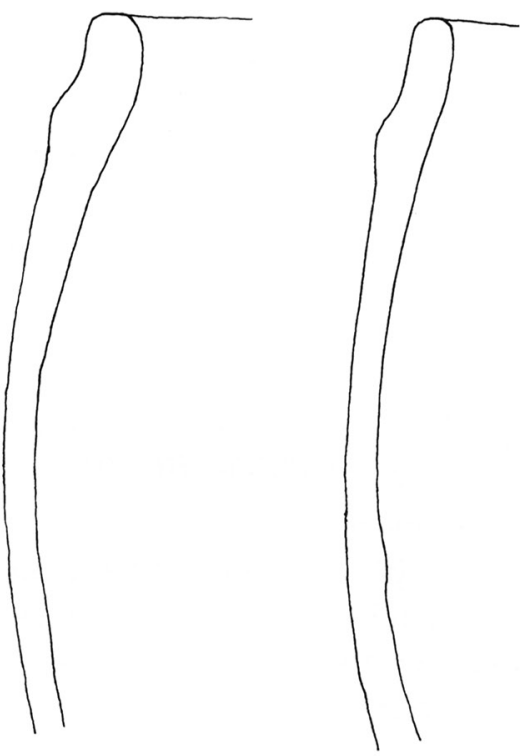

i hvert tilfælde i nyere tid, rektangulær eller sammentrykket mundingsrand (13).

\section{Dunke}

Der er i materialet fundet dele af et enkelt kar, som må betegnes som en dunk (fig. 14).

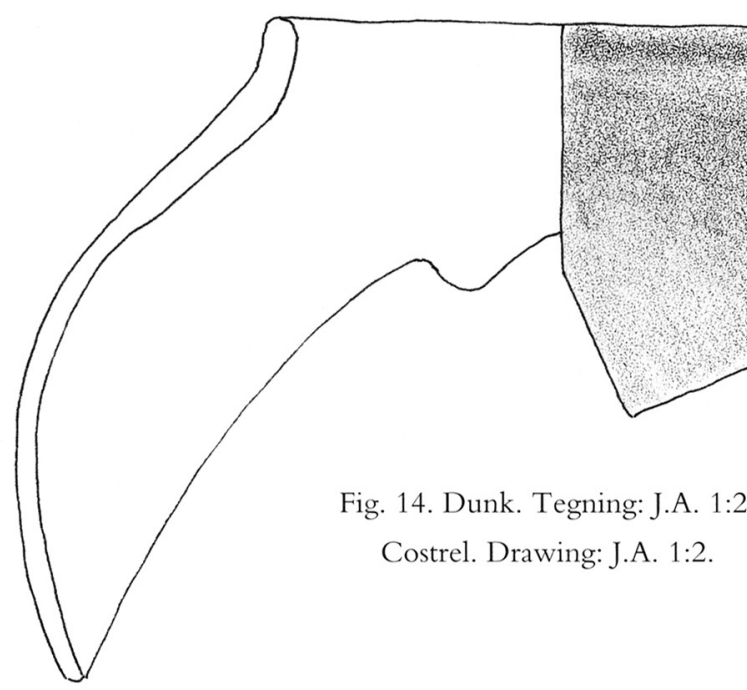


Hele randpartiet kunne sættes sammen. Karret har en randdiameter på $12,2 \mathrm{~cm}$. Randen er lodret og rundet, og har nærmest karakter af en meget kort hals. Den indvendige side af randen er glittet. Der er ikke hanke eller spor deraf på de bevarede dele af karret. Karret har en godstykkelse på ca. $0,5 \mathrm{~cm}$. I overgangen fra hals til skulder er der imidlertid en tydelig fortykkelse, som viser, at dunken ligesom kanderne er sat sammen af to selvstændigt fremstillede dele.

Bundens udformning kan der intet siges om, men karret må på grund af sin form nok tolkes som en beholder for væske.

\section{Lys og opvarmning}

Kakkelpotter

Kakkelpotterne udgør vægtmæssigt ca. $35,5 \mathrm{~kg}$, d.v.s. lidt mere end en tiendedel af hele fundet. De lader sig let udskille fra det øvrige materiale p.g.a. af godsets farve .

Der er ingen hele eksemplarer i fundet, men typen er velkendt (fig. 15) og lader sig let rekonstruere ud fra brudstykkerne. De har et kvadratisk mundingsparti med et tværmål på $16-20 \mathrm{~cm}$ og er ca. $12 \mathrm{~cm}$ dybe. Randen er lige og ufortykket, og er i hjørnerne kraget lidt ud. Den nedre halvdel af kakkelpotterne er rundet på både sider og bund. Kakkelpot-

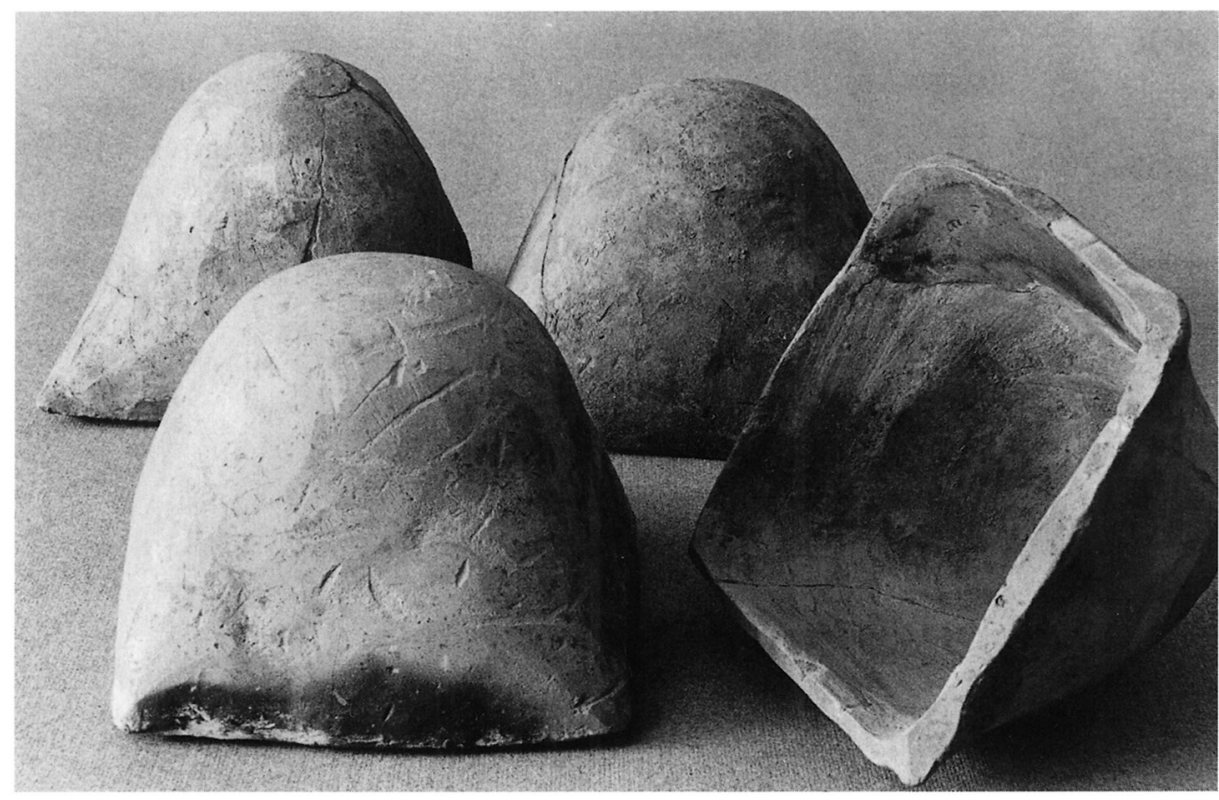

Fig. 15. Hele kakkelpotter fra fundet på Bundgårdsvej. Kakkelpotterne fra Paukærgård var af helt tilsvarende udformning. Foto: Edel Sørensen.

Complete stove files found at Bundgårdsvej. The stove tiles from Paukærgård had exactly the same shape. Photo: Edel Sørensen. 
terne er alle rødbrændte. Godstykkelsen varierer fra 0,5 til $0,8 \mathrm{~cm}$, idet kakkelpotternes sider ikke er efterbehandlede.

Der er grundlæggende tale om en senmiddelalderlig kakkeltype, idet formen dukkede op i 1400-årene. For de finere ovne gik denne kakkeltype af brug allerede ved middelalderens slutning (14), men på landet fortsatte man med at anvende den frem til midten af 1800-årene.

Kaklerne blev opmuret med ler til en kuppelformet ovn, en bilæggerovn. Ved en bilæggerovn foregik indfyringen fra et anden rum evt. køkkenet. Denne opvarmningsform havde den store fordel, at man slap for den generende røg i opholdsrummet, som ellers ville komme fra et åbent ildsted (15).

\section{Lampe}

I skårmaterialet var et fragment, som enten stammer fra en lysestage eller en fedtlampe (fig. 16a-b). Den helt nøjagtige funktion lader sig ikke bestemme, da fragmentet må tolkes som den nedre del af lampen/stagen.

Fragmentet, som er flækket omtrent midt igennem, er $7 \mathrm{~cm}$ højt. Fodstykket måler $11,3 \mathrm{~cm}$ i diameter, og er hvælvet på undersiden.

Stagens skaft er facetteret, men facetterne har forskellig bredde. Glitningen på stagen er næsten helt dækkende. På fodstykket er glitningen vandret, mens den på stangen er lodret. Også fodens undersiden er glittet.

Stagen/lampen synes at være blevet beskadiget allerede under brændingen. Skærven i bruddet er nemlig helt mørkegrå, mens den i nogle små afslag er lysegrå. Bruddet synes altså at have været udsat for brænding $i$ en reduceret atmosfære.
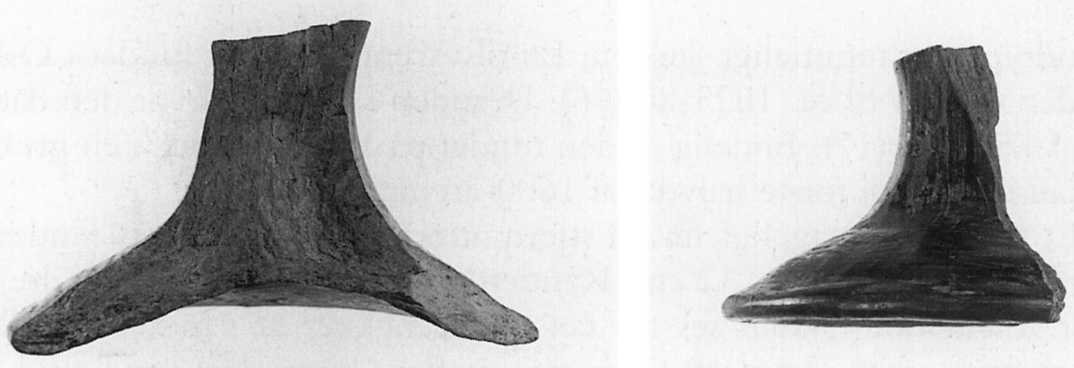

Fig. 16. Lampe/lysestage. a. Den lodrette brudflade gennem stagens fod. b. Stagefodens glittede yderside. Foto: Ole Brønden.

Lamp. a. Vertical fracture through the base of the lamp. b. The burnished surface of the lamp base. Photo: Ole Brønden. 


\section{Glaseret lertøj}

Denne artikels hovedemne er fundets jydepotter. Da jydepotterne imidlertid vanskeligt lader sig datere alene, vil jeg også behandle de få skår af glaseret lertøj, som blev fundet i forbindelse med jydepotterne, eftersom der burde være bedre muligheder for at datere disse. Det drejer sig om 27 skår fra i alt 10 stykker lertøj.

Den anvendte udgravningsmetode gør det desværre ikke muligt at henføre skårene til en bestemt del af gruben. Det store antal skår, som kunne samles til flager, og disses forholdsvis betydelige størrelser tyder på, at det glaserede lertøj i hvert fald ikke stammer fra muldlaget over gruben. Derimod kunne de eventuelt have ligget i sandlaget under jydepotterne.

Uanset problemerne med at fastslå de glaserede skårs nøjagtige indlejring i gruben, vil jeg her gå ud fra, at jydepotterne og de glaserede skår er deponeret indenfor en kort årrække, og at der således er tale om et sluttet fund.

De største og mest karakteristiske af de glaserede skår vil blive beskrevet $\mathrm{i}$ det følgende.

1) Det bedst bevarede stykke er resterne af en stjertpotte - 12 skår i 5 større skårflager - $\mathrm{i}$ alt en tredjedel af karret (fig. 17a). Stjertpotten har en randdiameter på $14 \mathrm{~cm}$. Randen er lodret og ufortykket med dekoration $i$ form af rullestempling med små ringe med fordybninger. Der er drejeriller på pottens yderside fra randpartiet til bunden. Midt på korpus er stjertpotten udsmykket med medaljoner i form af stemplede, påsatte lerklumper. Der er rester af mindst 4 medaljoner. Stjertpotten er udvendigt dækket af mørkegrøn glasur, medaljonerne er sorte, mens indersiden er dækket af gulgrøn glasur. Bunden er sodet udvendigt og glasuren noget ildskadet. Karret synes altså trods sin rige udsmykning at være anvendt som almindeligt kogekar. Ligeledes synes den ene tå, som er bevaret, på et tidspunkt at være knækket og slebet til, så potten stadig kunne anvendes.

Randtypen er temmeligt sjælden. En tilsvarende rand er fundet i Oslo, hvor den dateres til ca. 1625-80 (16). Desuden i Malmø, hvor den dateres til 1670'erne (17). Endelig er den fundet på Vilhelmsborg i en grube, som kan dateres til første halvdel af 1600-årene (18).

2) Et randskår antageligt fra en stjertpotte (fig. 17b). Karrets randdiameter kan beregnes til ca. $12 \mathrm{~cm}$. Randen er let udadbøjet med tre drejevulster. Nedenfor randen ses tre tætstillede rækker af vandrettte rullestempelaftryk, som synes at fortsætte opefter, hvor den imidlertid er dækket af glasur. Både ud- og indvendigt er skåret dækket af rødbrun glasur.

Der er ligeledes her tale om en noget usædvanlig randudformning. Tilsvarende randformer er fundet på Sorø fattiggård, hvor de imidlertid ikke 

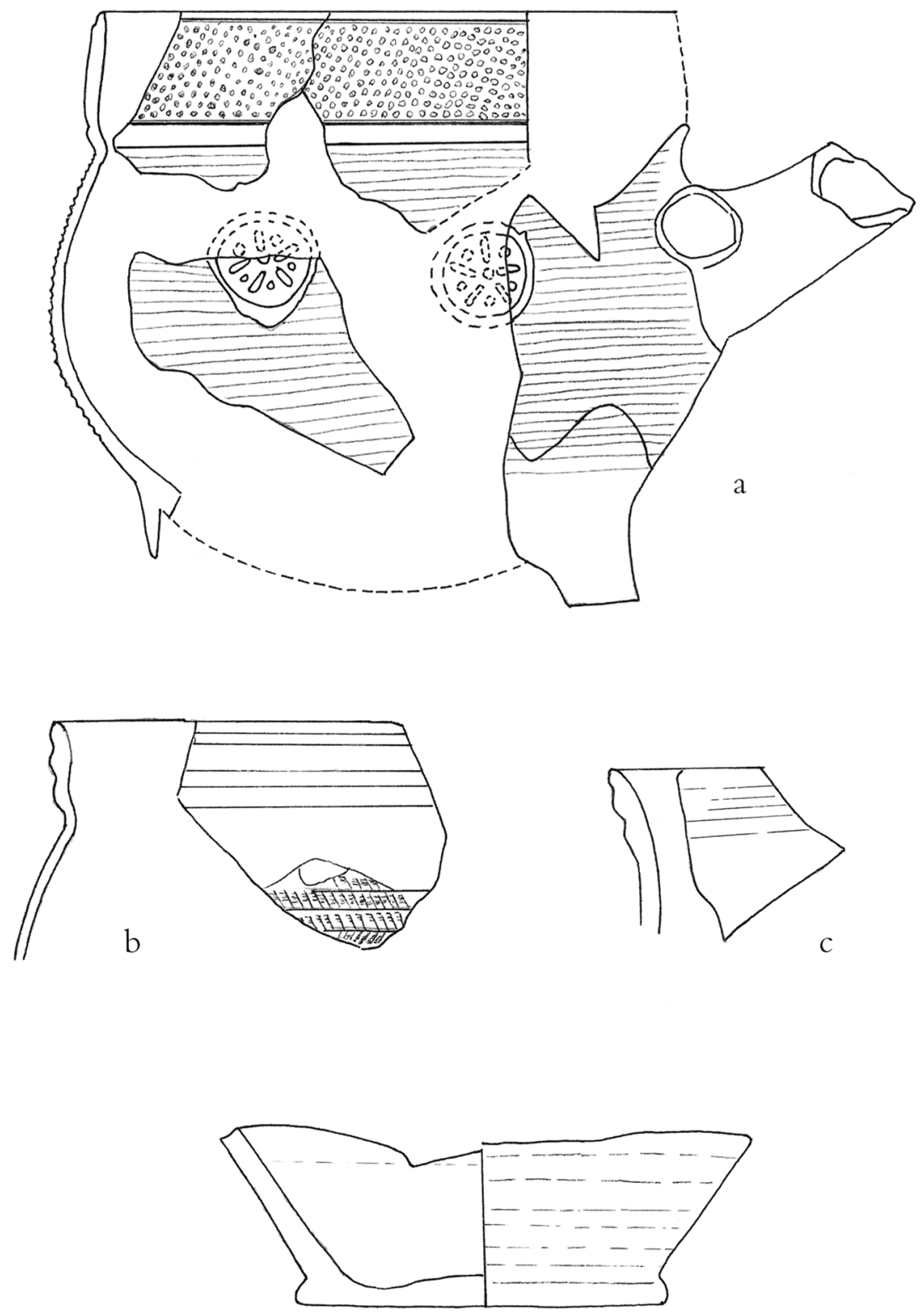

d

Fig. 17. a. Glaseret stjertpotte - glaseret lertøj nr. 1. b. Randskår af glaseret stjertpotte - glaseret lertøj nr. 2. c. Randskår af glaseret stjertpotte - glaseret lertøj nr. 3. d. Bundparti af glaseret skål glaseret lertøj nr. 5. Tegning: J.A. 1:2.

a. Glased earthenware no. 1. b. Rimsherd of glazed longhandled pot - glazed earthenware no. 2. c. Rimsherd of glazed longhandled pot - glazed earthenware no. 3. d. Glaced bowl - glazed earthenware no. 5. Drawing: J.A. 1:2. 
kan dateres nærmere (19), i Oslo, hvor den er fundet i en sammenhæng, som dateres til ca. 1625-80 (20) og på Vilhelmsborg fra første halvdel af 1600-årene (21). Et lignende randskår er fundet i Ribe, hvor det dateres til midten af 1600-årene (22).

3) Et randskår antageligt fra en stjertpotte (fig. 17c). Skåret er for lille til, at randdiameteren kan beregnes. På ydersiden ses tre tætstillede drejevulster. Både inderside og yderside er dækket af grøn, spættet glasur.

Der er tale om en almindelig randtype. I Oslo forekommer den i perioden ca. 1625-1680 og fremefter (23) og i Sorø fattiggård, hvor fundene ikke kan dateres nærmere end ca. 1680-1856 (24).

4) Et bundskår antageligt fra en øreskål, bevaret i $3,5 \mathrm{~cm}$ højde med hele standfladen bevaret. Standfladen er trukket ud i forhold til karsiden. På ydersiden tydelige drejeriller. Godset er gulligt; indvendigt er det dækket af en tyk grøn glasur, udvendigt gulglaseret.

5) Et bundskår antageligt fra en øreskål (fig. 17d). Bevaret i $4,5 \mathrm{~cm}$ højde med hele standfladen bevaret. Ligesom glaseret kar nr. 4 har bundskåret fremtrædende standflade, som dog her er noget afrundet. På ydersiden er tydelige drejeriller. Indvendigt i bunden ses en "drejetop". Karret er ud- og indvendigt samt delvist under standfladen glaseret med olivengrøn glasur med mørkegrønne pletter.

6) Fire skår af en skål, nok til at rekonstruere hele dens form (fig. 18a). Skålen har en randdiameter på $24 \mathrm{~cm}$. Standfladen måler ca. $10 \mathrm{~cm}$ i diameter. Dens højde kan beregnes til ca. 6,5 cm. Der ses ingen spor af ører på randskårene. Godset er gulrødt og karrets inderside er dækket af en mat, gulliggrøn glasur med grønne pletter.

7) Fem skår af en skål, som kan samles til 2 flager, nok til at rekonstruere hele karrets form (fig. 18b). Det drejer sig om en stor, forholdsvis lav skål med to modstillede, vandrette ører. Randdiameter er ca. $26 \mathrm{~cm}$, standfladen ca. $14 \mathrm{~cm}$ i diameter og højden $8,2 \mathrm{~cm}$. Randen er lodret og på dens yderside ses en bred rullestempeldekoration. Godset har en rødgul skærv. Skålens inderside er dækket af en gulgrøn glasur; ydersiden, herunder også ører, er uglaseret. Ved en brudflade i bunden ses et $0,24 \mathrm{~cm}$ stort, boret hul i en afstand af $1,3 \mathrm{~cm}$ fra bruddet - formodentlig spor efter en klinkning.

Som det ses, er det vanskeligt at datere de glaserede kar nøjagtigt, da der kun er publiceret et meget begrænset sammenligningsmateriale. De paralleller, jeg har fundet, peger dog overvejende mod 1600-årene. Dog er karrene antageligt yngre end ca. 1620, idet deres udformning ikke ligner materialet $i$ tre større publicerede, danske fundkomplekser, som dateres til perioden frem til ca. 1620 (25). Den øvre afgrænsning af dateringen er endnu vanskeligere at udrede, da der næsten ingen keramikfund er publiceret for resten af 16- og 1700-årene. Det er derfor vanskeligt at få et indtryk af, hvilke ændringer lertøjet undergik i løbet af perioden. Dog 


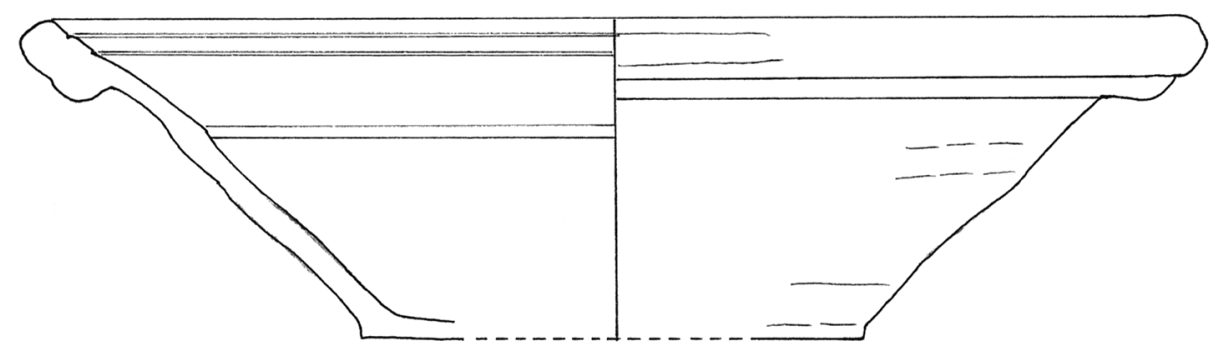

a

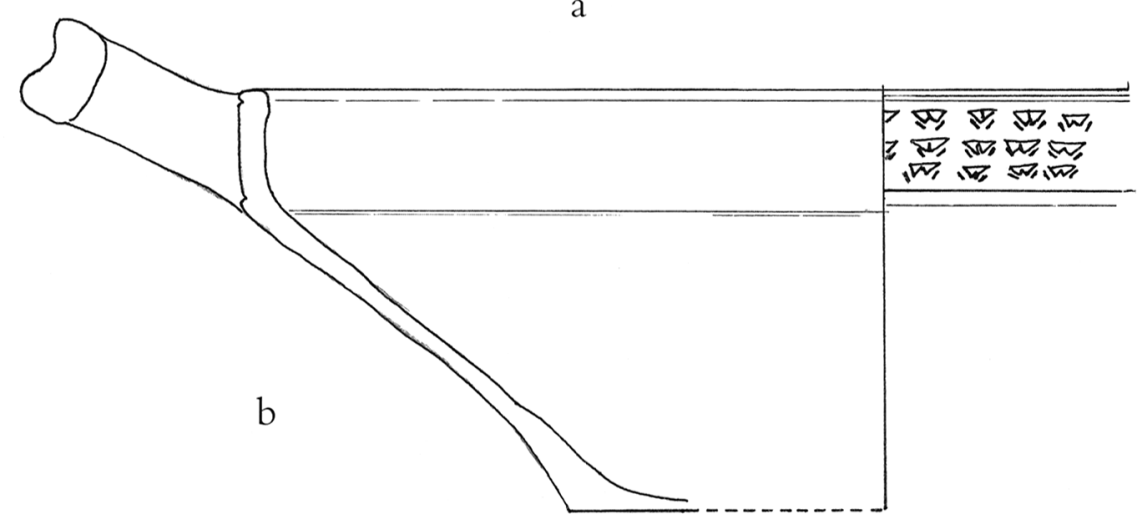

Fig. 18. a. Glaseret skål - glaseret lertøj nr. 6. b. Glaseret skål - glaseret lertøj nr. 7. Tegning: J.A. $1: 2$.

a. Glazed bowl - glazed earthenware no. 6. b. Glazed bowl - glazed earthenware no. 7.

Drawing: J.A. 1:2.

er der publiceret fund fra Hans Egedes hus i "Håbets Koloni" fra 1720'erne (26) og materiale fra en kælderopfyldning fra 1780'erne i Sønderborg (27). Der var i disse to fund ingen nære paralleller til fundene fra Vester Brønderslev.

Desuden har jeg haft mulighed for studere to større opsamlinger af keramik fra Vilhelmsborg, som kan dateres til henholdsvis første halvdel af 1600-årene og til ca. 1770 (28). Der var en tydelig forskel i karakteren af lertøjet i de to opsamlinger, og materialet fra Vester Brønderslev har flest træk til fælles med lertøjet fra den ældste. På grundlag heraf og med henvisning til det ovennævnte forholdsvis beskedne sammenligningsmateriale, vil jeg foreslå en datering af det glaserede lertøj i gruben med jydepotter til ca. 1650-1700. En datering, jeg vil tillade mig at overføre til jydepotterne. 


\section{Jydepotteproduktionen i Vester Brønderslev i skriftlige kilder}

De fejlbrændte potter er ikke de eneste spor, pottemagerne i Vester Brønderslev har efterladt sig; også i de skriftlige kilder nævnes deres aktiviteter. Disse spor er dog både spredte og ukomplette, men når man vil forsøge at sætte de fundne jydepotter ind i en kulturhistorisk sammenhæng, er de alligevel vigtige.

Første gang der i de skriftlige kilder gives en antydning om en produktion af jydepotter i Brønderslev er ved midten af 1600-årene. En mand stod 1653 tiltalt for at have taget tørv i Burholt og have kørt dem til "grydefolkene". En tidligere dom, fra 1639, hvor en række personer forbydes at handle på Hjørring marked kan muligvis også have forbindelse til potteproduktionen (29).

Næste gang pottemageriet omtales, er i en rejseberetning fra 1763. Heri nævnes blot, at "I Vester Brønderslev gøres sorte gryder" (30). Samme kortfattede oplysning giver Pontoppidan i sit "Danske Atlas" fra 1768 (31).

Det er vanskeligt at få et indtryk af produktionens omfang. Fra 1767 foreligger en oplysning om, at Hundslund Marked, nu Hjallerup Marked, blev tilført 12 læs sorte potter (32). Det er imidlertid først ind i 1800-årene, at vi får mere udtømmende oplysninger. Amtmand BrinckSeidelin kan således i sin beskrivelse af Hjørring Amt fra 1838 oplyse, at "I Vester Brønderslev ernære 10 Familier sig tildels ved brænding af sorte Potter". Brinck-Seidelin havde ikke høje tanker om produktionens omfang og lønsomhed. Da man måtte hente leret langvejs fra og leje vogne til at transportere varerne til marked i, mente han, at potteproduktionen kun gav ringe udbytte. Produktionens ringe omfang understreger han ved at nævne, at der på markederne i Hjørring Amt solgtes mange potter fra Randers-egnen (33). Et publiceret fund af jydepotter i Oslo tyder imidlertid på, at der tidligere fandt en vis eksport sted. Især kandernes udformning og dekoration er så karakteristisk, at man kunne fristes til at tro, at de var fremstillet af "vor" pottekone (34).

Præcis hvornår produktionen ophørte, kan ikke afgøres med sikkerhed. Af C. Nyrop's værk "Dansk Pottemageri" fra 1882 fremgår det, at produktionen da var fuldstændig forsvundet p.g.a. konkurrencen fra jerngryderne (35). Det stemmer godt med Klitgaards oplysning om, at produktionen vedblev til 1860-70'erne (36). I J.P. Traps Danmarksbeskrivelser fra 1859 og 1875 angives det, at landbrug var hovederhvervet for beboerne i Vester Brønderslev, men at der afsattes en del husflidsprodukter - om der her henvises til jydepotter er uvist, men det forekommer da sandsynligt (37). I Traps udgave fra 1901 nævnes intet om denne husflid, men da havde Vester Brønderslev også antaget bykarakter p.g.a. anlæggelsen af den jyske længdebane. 
På grund af de få oplysninger lader produktionens nøjagtige omfang og $ø$ konomiske betydning sig ikke afgøre. Hovedindtrykket må dog indtil videre blive, at pottemageriet i Vester Brønderslev var af beskedent omfang sammenlignet med produktionsområderne ved Randers og Varde.

Spørgsmålet om hvem, der stod for produktionen, lader sig dog delvist besvare af de skriftlige kilder. I folketællingslisterne fra 1781 og 1801 er der ingen personer i Vester Brønderslev, der er anført som pottemagere. Der har altså ikke været tale om egentligt professionelt håndværk, men snarere om en slags hjemmeindustri. C. Klitgaard refererer i sin bog om Vester Brønderslevs historie en beretning af N.C. Larsen Bundgaard, som levede i Brønderslev 1808-81. Larsen Bundgaard kunne huske 11 af pottemagerne af navn. Det drejede sig ifølge Klitgaard almindeligvis om husmændenes koner. Bundgaard nævnte dog også grydepiger i sin beretning (38).

Disse oplysninger stemmer godt overens med forholdene, som de er kendt i de øvrige jydepotteområder, hvor pottearbejdet blev udført af kvinder. I nogle af disse områder var hele sogne beskæftiget med pottemageri. Man kunne her se, at gårdmænd fæstede "grydepiger" for sommeren. I Vester Brønderslev synes erhvervet imidlertid knyttet til de laveste sociale lag. Dette understreges af Brinck-Seidelins oplysninger $\mathrm{om}$, at man måtte leje vogne til at transportere potterne til marked i.

Med pottemageriets sociale placering således fastslået, ville det være interessant at vide, hvorfor netop Vester Brønderslev blev et center for produktionen af jydepotter i Vendsyssel. I de sydligere egne af landet forklares pottemageriets udbredelse med dårlige landbrugsforhold og arge jorder. Dette kunne også gælde for Vester Brønderslevs vedkommende, idet jordbunden i Trap's 1859-udgave beskrives som "kold og fugtig, besværet af skadeligt Vand og derfor mindre frugtbar" (39). Samtidigt synes Vester Brønderslev at have været den landsby i Vendsyssel, som havde flest husmænd; I 1682 var der således 27 gårde og 46 huse med jord samt et jordløst hus (40). Potteproduktionen skal således antagelig ses som supplement til et for ringe afkast af jordbrug og dagleje for husmændene. Råmaterialet til pottefremstillingen har kunnet hentes $\mathrm{i}$ den umiddelbare nærhed af byen. Leret blev ifølge Klitgaard taget ved Døvling syd for byen og på Dammens Hede og altså ikke, som Brinck-Seidelin hævdede, langvejsfra (41). Tørvene til brænding af potterne kunne ligeledes hentes inden for sognets grænser. Jydepottemageriet kan således betragtes som en kapitalekstensiv virksomhed - en drift som kun krævede fă og billige ressourcer, men til gengæld ganske stort tidsforbrug og håndelag. Altså en gunstig måde at forøge sine sparsomme indtægter på i et sogn, hvor mulighederne for yderligere ekspansion af dyrkningen ikke var til stede. 


\section{LITTERATUR}

Andersen, B. og J. Slettebo: Kirkegade 8, Senderborg. Fra Als og Sundeved bd. 67, 1989.

Barfod, L.: Ingen nød i potteland. Skalk 1966:4.

Berg, H. et al.: Sandhagen. Et langelandsk fiskerleje fra renaissancen. Rudkøbing 1981.

Billberg, I.: Från Trattbägara til Fajans. Malmøya 5, 1987.

Brinck-Seidelin, L.C.: Hjørring Amt. København 1828.

Gulløv H.C. og H. Kapel: Haabetz Colonie 1721-1728. Ethnohistorical studies of the meeting of eskimo and European cultures I. København 1979.

Højrup, O.: Borddækning og bordskik blandt bønder fra 1600 til 1900. Arv og Eje 1977.

Iversen, $M$ og U. Nüsman: En $2 \frac{1}{2} 2$ tusind år gammel ildgrav i Troestrup. MIV-Museerne $i$ Viborg amt 8, 1978.

Jensen, A.G.: Jydepotten. København 1924.

Jensen, V.: 1400-årenes lertøj i Kolding. Hikuin 8, 1982.

Klitgaard, C.: En rejse i Vendsyssel 1763. Vendsyssel Aarboger 1925-26.

Klitgaard, C.: Vester Brønderslevs Historie. Brønderslev 1942

Kristiansen, O.: Finder I noget? En arkæologisk undersøgelse af tomten for det gamle fattighus i Sorø. Sorø Amts Museum 1916-1991, 1991.

Larsen, J. Linaa: Keramik fra Torvet $i$ Horsens. - Typologi, proveniensbestemmelse og datering. Højbjerg 1995.

Liebgott, N.-K. : Kakler. København 1972.

Liebgott, N.-K. : Stakhaven. Arkcoologiske undersøgelser i senmiddelalderens Dragør. København 1979. Lysdahl, P.: Tre års arkæologi. Vendsyssel Nu og Da 3, 1979.

Madsen, H.J.: Skumstrup - Vilhelmsborg. En herregårdstomt fra renæssancen. Hikuin 18, 1992.

Madsen, P.K. \& O. Schiørring: En udgravning i Ribes "nye grav" og et fund af keramik fra 1500-1600-årene. Hikuin 7, 1981.

Molaug, P.B.: Blyglaseret leirgods. I E. Schia (red.): Fra Christianias bygrunn. Øvre Ervik 1981.

Molaug, P.B.: Leirkarmaterialet. I E. Schia (red.): Sendre Felt. De arkeologiske utgravninger $i$ Gamlebyen, Oslo bd. 3. Øvre Ervik 1987.

Nyrop, C.: Dansk Pottemageri. København 1882.

Pedersen, H.: De danske Landbrug. København 1928.

Pontoppidan, Erik: Den danske Atlas V. København 1768.

Riismøller, P.: Pottemageren i Pederstræede. Kuml 1970, 1971.

Schia, E.: "Jydepotter". I E. Schia (red.): Fra Christianias bygrunn. Øvre Ervik 1981.

Trap, J.P.: Kongeriget Danmark, København 1859, 1875 \& 1901.

\section{NOTER}

Sagen har på Vendsyssel historiske Museum journalnummer VHM 135/1978 Paukærgård, Brønderslev sogn, Børglum herred

Jeg vil gerne takke museumsinspektør Per Lysdahl, Vendsyssel historiske Museum, for at have fået lov til at arbejde med materialet, og for vejledning og gode råd henad vejen. Desuden vil jeg gerne takke museumsinspektør H.J. Madsen, Forhistorisk Museum, Moesgård, fordi han var så venlig at låne mig manuskriptet til sin dengang utrykte artikel om Vilhelmsborg og for at have givet mig adgang til selv at se fundmaterialet fra Vilhelmsborg.

1) Jensen 1924 s. $53 \mathrm{ff}$.

2) Jensen 1924 s. $47 \mathrm{ff}$.

3) Jensen 1982 s. 103 og Larsen 1995 s. $130 .$.

4) Jvf. Jensen 1924 s. $10,165 \mathrm{ff}$.

5) Jvf. Jensen 1924 s. 125.

6) Beretning VHM 135/1978. Fundet er kort omtalt i Lysdahl 1979, s. 25.

7) Jvf. Jensen 1924 s. 39, Barfoed 1966, Iversen \& Näsman 1978, Lynggaard 1972 s. $41 \mathrm{ff.}$.

8) Jensen 1924 s. 127.

9) Schia 1981 s. 113/fig. 3: R 3891 og især 7952.

10) Jensen 1924 s. 135.

11) Schia 1981 s. 114 , fig. 5 .

12) Højrup 1977 s. 106-108. 
13) Jensen 1924 s.133-34.

14. Liebgott 1972 s. 16.

15) Jensen 1924 s. 146-147.

16) Molaug 1981 s. 73, fig. 21:1.

17) Billberg 1987 nr.139

18. Madsen 1992 s. 209ff. \& FHM 1978V.

19) Kristiansen 1991 s.106-107.

20) Molaug 1981 fig. 7:5.

21) Madsen 1992 s. 209ff. \& FHM $1978 \mathrm{~V}$.

22) Madsen \& Schiøring 1981 s. 239.

23) Molaug 1981 s. 64, fig. 6:1 og s. 65, fig. 7:7.

24) Kristiansen 1991 fig. 21:6.

25) Licbgott 1979 s . 8()-83, Berg et al. 1981 fig. 36 \& 44, Riismøller 1971.

26) Gulløv \& Kapel 1979.

27) Andersen \& Slettebo 1989

28) Madsen 1992 og FHM $1978 \mathrm{~T} \& \mathrm{~V}$.

29) Klitgaard 1942 s. 42.

30) Klitgaard 1926 s. 323

31) Pontoppidan $1768 \mathrm{~V}, 1$ s. 290.

32) Klitgaard 1942 s. 42.

33) Brinck-Seidelin 1838 s. 311-12.

34) Schia 1981 s. 114, fig. 5 - også fig. 3: R 3891 og 7952 og fig. 2: R 11972 synes at have nære paralleller i materialet fra Brønderslev. De udvendigt mønsterglittede kar, fig. 6: R 12088 og fig. 4: R 10957 er derimod uden lighed med fundet fra Brønderslev.

35) Nyrop 1882 s. 9.

36) Klitgaard 1942 s. 42.

37) Trap 1859 s. 75,1875 s. 88.

38) Klitgaard 1942 s. 48 . Den originale beretning er forgxves eftersøgt.

39) Trap 1859 s. 75.

40) Pedersen s. 315.

41) Klitgaard 1942 s. 42.

\section{Jutish ware from Brønderslev}

Until the beginning of the 2()th century black, clamp-fired earthen ware, so called jutish ware, was still produced at a few places in Jutland. The peak of the production was around 1840), at which time it is believed that 1,8-1,9 million vessels were produced per year. The production of the pottery was a sideline to farming. However in some districts the work was done so intensively, that it almost had the character of a professional trade, as servant girls in the summer were explicitly employed to produce pots.
There were several centres of production primarily in the south-western and middle part of Jutland. From written sources it is known that jutish ware was produced in the village of Vester Brønderslev in northern Jutland. As the production is believed to have been in modest quantities and stopped quite early, very little is so far known about the vessel shapes and types.

This article will present the vessel types from a large find of jutish ware made near the farm of Paukjærgard in Brønderslev. 
The find consists of $3(05$ kilograms of sherds of Jutish ware, which are probably waste from manufacturing. This is not the only find of large quantities of jutish ware made in and around Brønderslev (fig. 3); in 1959 and 1971 large amounts of sherds were dug up in and around the town. The documentation of these other finds is however too poor to offer the basis for more thorough analyses.

\section{Site and excavation}

The find was made in april 1978 when a pit containing a large quantity of sherds was cut during trench digging on the south-eastern edge of the town of Brønderslev.

The pit had been dug c. $1 \mathrm{~m}$ into the subsoil and measured c. 5,5 $\mathrm{m}$ at the top. In the bottom of the pit was a c. 3() $\mathrm{cm}$ thick layer of downwashed sand over which was a 3() $\mathrm{cm}$ thick, compact layer of sherds and a few lumps of clay. (fig. 1 and 2) Between the sherds was black soil.

The original purpose of the pit could not be stated with certainty. The depth of the pit and the lack of ash, however, indicates that it was not a kiln. It's more likely to have been a sand pit, as the subsoil was sand.

After a rather sketchy recording of the profile, the sherd layer was excavated. This was done with a mechanical excavator by first removing the top soil, and carefully placing the shovel under the sherd layer, which was taken up in lumps.

\section{General descripition of the material}

The vessels are handmade, i.e. pressed out in the clay without the use of a throwing wheel. After shaping the vessels the surfaces of most vessel types were smoothed by scraping and partial burnishing.

The fabric of the sherds is generally light grey and the clay has been tempered with fine sand. Most of the sherds are $c$. (),5 cm thick. The surfaces of the vessels are black with burnishing, the extent of which however depends on the vessel type.
The very homogeneous character of the sherds might suggest alone indicate that it is manufacturing waste. Because of the relatively low firing temperature and the high degree of fragmentation of the sherds only a few definite signs of misfiring can be established. However fairly many sherds with cracked or flaking surfaces can be seen. Furthermore there are no traces of the vessels having been used before discarding, such as wear on feet and bases or traces of burnt food.

\section{Vessel types}

The vessels can be divided into four functional groups: I. Cooking vessels, II. Table vessels, III. Storage vessels, IV. Vessel for lighting and heating.

\section{Cooking vessels}

Long-handled pots (fig. 4 \& 5)

In the find are 33 long handles most probably from tripod cooking pots. The rims of the vessels has a diameter of 2()-22 cm and are everted (fig. 4a-b). A single vessel has incurved rim and a rim diameter of only $16 \mathrm{~cm}$ (fig. 4c). As it is general to all of the cooking pots, burnishing is restricted to the rim and the internal side of the bottom.

Long-handled pans (fig. 6)

C. 5 handles from tripod frying pans are found. The pans had a diameter of c. 2627 and are 3,5-4,7 $\mathrm{cm}$ deep.

\section{Sinall pots (fig. 7)}

The few small pots in the find had rim diameters of $\mathrm{c} .11 \mathrm{~cm}$. A single loop handle is fastened to the rim and the vessel side. Two types of bases for the small pots are found, tripod and a flat.

\section{Roasters}

The roasters had a rim diameter of 2()-22 $\mathrm{cm}$ and are 8,(0-9,3 $\mathrm{cm}$ deep. The rim shape is quite alike for all vessels, but the shape of the bases differed much and could either be slightly rounded, upbend or flat.

\section{Large cooking pots (fig. $8 \&$ 9)}

The most frequent vessel type in the find 
is the tripod cooking pot. The rim diameters in this category vary from 18 to 32 $\mathrm{cm}$; however two distinct sizes with rim diameters of $18-20$ and $28-30 \mathrm{~cm}$ can be distinguished. The shapes of the rims vary considerably, but all were everted.

\section{Table vessels}

Jugs (fig. 10)

The jugs of the find are rather round-bellied with strap handles attached to rim and belly. Extensive patterns of burnishing are seen on the outer surfaces. The body and the necks consisted of two separately formed parts.

\section{Bouls (fig. 11)}

The bowls had a rim diameter of 22-28 $\mathrm{cm}$ and were $8-10 \mathrm{~cm}$ deep. The inner surface of most of the vessels is burnished. On a few however only the rim is totally burnished with a lozenge pattern of slanting lines of burnishing on the rest of the inner surface.

\section{Small boul (fig. 12)}

A large fragment of a single small bowl is found. The bowl has a rim diameter of 15 $\mathrm{cm}$ and is at least $4 \mathrm{~cm}$ deep. The shape of the base is unknown as it is not preserved. The sides are $(0,3 \mathrm{~cm}$ thick, gradually increasing to ()$, 5 \mathrm{~cm}$ at the rim. All of the internal part of the vessel is burnished.

\section{Plates}

Only a few fragments from plates are found. The plates had a diameter of c. 27 $\mathrm{cm}$. The depth of the plates varies from 3,4 to $5,7 \mathrm{~cm}$. The thickness of the plates varies between ()$, 6$ and $1,() \mathrm{cm}$.

\section{Storage vessels}

Coarse vessels (fig. 13)

In the find $12 \mathrm{~kg}$ of distinctly thicker and coarser sherds can be sorted out, representing at least 6 vessels. The sherds has very uneven surfaces with no signs of any smoothening or burnishing. Their thickness varies from $(0,45$ to $(0,9 \mathrm{~cm}$ within short distances. The rims are all incurved but vary so much that each vessel had its own specific rim shape. The rim diame- ters varied from 32 to 4() $\mathrm{cm}$. Little can be said about the vessel shape, but one flat base with a diameter of $16 \mathrm{~cm}$ is found.

\section{Costrel (fig. 14)}

A single fragment of the mouth part of a costrel is found. The vessel has rim diameter of 12,2 cm., the rim being vertical. There are no traces of handles. The neck and the body are formed as two separate parts.

\section{Light and heating}

Stove tiles (fig. 15)

Stove tiles form c. $35,5 \mathrm{~kg}$ of the find, i.e. a bit more that $1 / 10$ of its weight. The sherds are easily distinguished from other sherds as they are coarser and all fired red. The stove tiles has a square, $16-2() \mathrm{cm}$ wide rim and are $12 \mathrm{~cm}$ deep.

Lamp (fig. 16a-b)

A single fragment stems from a candlestick or an oil lamp. The exact use cannot be determined as the upper part is missing. All original surfaces of the vessel are burnished.

\section{The dating of the find}

Jutish ware is in general hard to date on its own terms. To get a reliable date it is therefore necessary to make a close study of 27 sherds from 10 pieces of glazed pottery (fig. $17 \& 18$ ), which were also found in the pit. The glazed pottery can with some uncertainty, which is partially due to the paucity of published finds, be dated to the period c. 165()-17()().

\section{The manufacturing of jutish ware in Bronderslev}

The production of jutish ware in the village of Bronderslev is first mentioned in written sources from the mid 17th century. These mentions are however mostly very brief. The only more detailed assessment of the production is made by the local prefect in 1838. At this date 10) families were said to support themselves partially by producing pottery. The prefect had a low opinion of the product. He underlined the modest size of the industri by 
pointing out that on the markets of the county many vessels produced in Vorup (near Randers in eastern Jutland) were sold.

Production of jutish ware in Bronderslev probably ended in the 1860's or 187()'s. The reason for the end of the production was the spread of the iron stove, for which earthenware was unsuited.

The social context of the production of jutish ware in Bronderslev is only known from about the time when production ended. At that time the pottery was mostly produced by the smallholders' wives. The non-professional character of the production is underlined by the fact that in census papers for Brønderslev from 1781 and 1801 no person is designated as "potter".

Probably Brønderslev became a centre for the manufacture of this ware only to supplement agricultural production.

Jens Andersen

Odense Universitet

Oversattelse: David Liversage 